\title{
Tinginstitusjonens alder i Skandinavia belyst ved arkeologi og stedsnavnsgransking - samsvar eller ikke?
}

Tinget i Norden har hatt en fundamental plass som forum for samhandling og konfliktløsning. Sosiale, økonomiske, militære, politiske og religiøse/kultiske elementer har også vært innvevd i ulik grad. Relativt få tingsteder før tidligmoderne tid er sikkert belagt arkeologisk. I liten grad er også den eksakte lokaliseringen kjent gjennom stedsnavn. Til tross for den vesentlige institusjonen som tinget har vært i samfunnet helt opp til moderne tid, så vet en i liten grad hvordan et forhistorisk tingsted faktisk så ut. Dette har skapt problemer for forskere, særlig knyttet til identifikasjon av tingsteder og aldersbestemmelse. Den første som nevner tinget i Nord-Europa var Cæsar i 50 f.Kr. I 98 e.Kr. beskriver romeren Tacitus hvordan germanske stammer holdt sine samlinger (Iversen 2013). Når tinget begynner å tre frem i kildene om Norden, fra rundt 900 e.Kr. og senere, er det under stadig påvirkning av kongemakt og senere kirken, men en vet i liten grad hvor langt tilbake tinget kan føres her. De kildene som best kan belyse forhold bakover i tid er arkeologi og stedsnavn, og de vil derfor bli benyttet her for å se nærmere på hva tingorganisasjonen er og når den oppstår. Dette vil bli undersøkt i Skandinavia, der tinget er godt kjent i middelalderen. Det vil også bli trukket veksler på materiale fra Færøyene og Island, som hadde bosetning først fra 800-tallet, og der tinget følgelig først er kjent i etterfølgende periode (figur 1).

Hvor langt tilbake i tid går tinget før det ikke lenger er gjenkjennbart som den institusjonen vi kjenner fra middelalderen i Skandinavia? Er det samsvar mellom arkeologi og stedsnavnstolkninger av tingets alder? Et vesentlig moment er dermed å forsøke å belyse når institusjonen får en mer offentlig karakter i form av en organisasjon. Først skal det kort diskuteres hvordan ulike forskere har nærmet seg disse kompliserte spørsmålene. Deretter skal metodene for å undersøke tinget arkeologisk og gjennom stedsnavn diskuteres. For å kunne studere tinget over tid må tinget som institusjon med visse fellestrekk avgrenses. Her vil det derfor bli definert to analytiske kategorier, det arkeologiske tingstedet og stedsnavnstingstedet. Disse må så vurderes kontekstuelt, før det blir undersøkt om de to kategoriene bekrefter, utfyller eller motstrider med hverandre. For å studere tingets alder mer konkret, vil tre case-studier bli diskutert. 


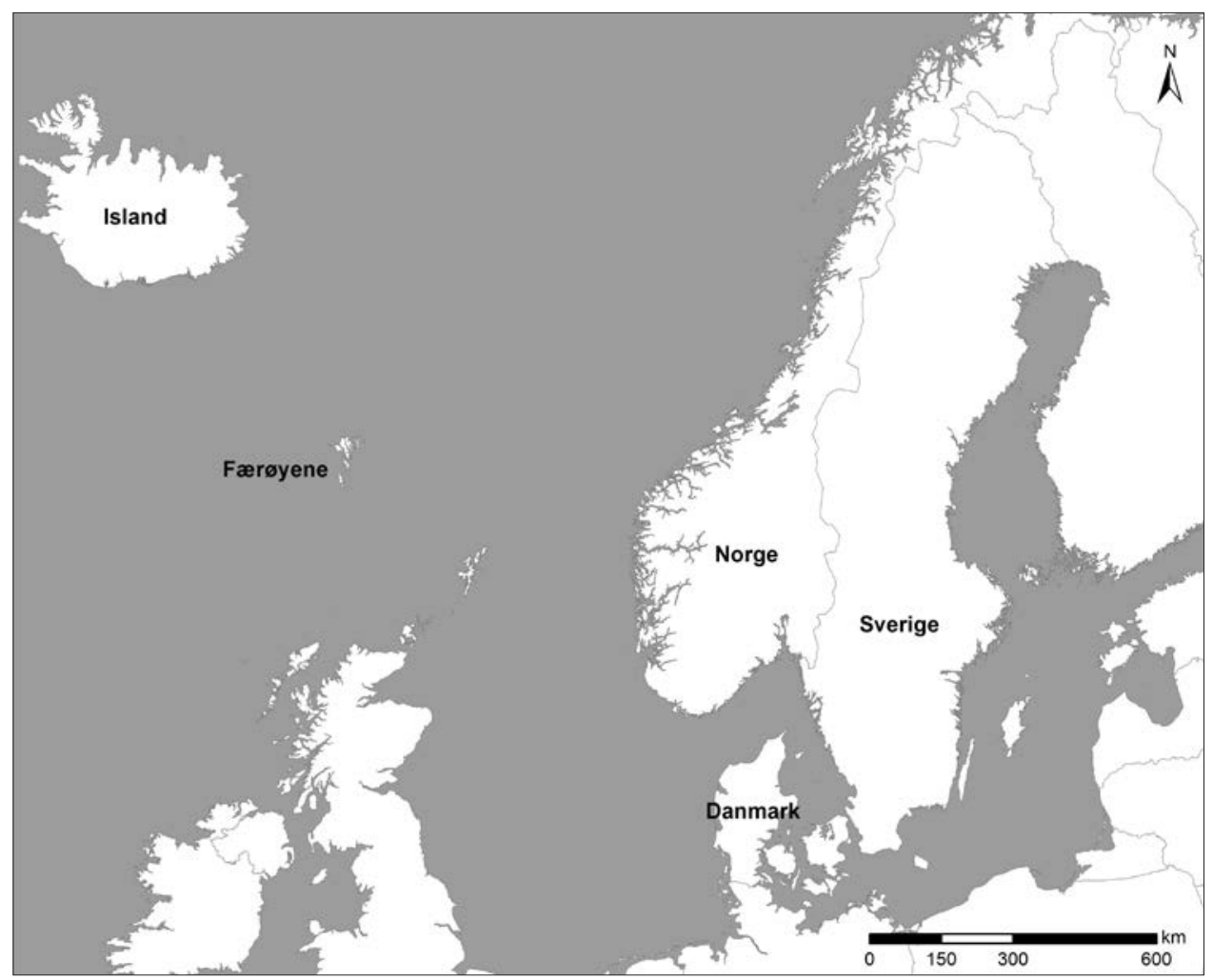

Figur 1. Oversikt over undersøkelsesområde. Kartgrunnlag: Statens kartverk.

Tillatelsesnummer NE12000-150408SAS. Illustrasjon: Marie Ødegaard.

\section{Forskningshistorie og forskningsstatus}

Arkeologi og sammenlignende språkkunnskap fikk gjennombrudd som forskningsgrener på begynnelsen av 1800-tallet (Dahl 1990:38). En tenkte seg da at det hadde vært et språklig og kulturelt fellesskap i Norden i jernalderen og tidligere. Dette fellesskapet ble koblet til begrepet germanere, som i klassiske kilder var folkene nord for Romerriket i århundrene etter Kristus (Sandvik 1989). De nordiske landene skal ha bestått av en rekke grupper og stammer. En anså at distriktsbetegnelsen fylke i Norge, som er avledet av ordet folk, skal ha utgjort egne kongeriker (Munch 1849; Keyser 1867:6). En tilsvarende hypotese ble satt frem for begrepet land i Sverige og Danmark (Tunberg 1911:3). Tolkningen av distriktsbetegnelsen som egne kongeriker er senere blitt avvist av forskere (Bull 1930:104; Indrebø 1931:35). Tinginstitusjonen ble datert nærmest direkte fra opplysninger i landskapslover og sagaer. På den måten ble de fire lagdømme-tingstedene og lagdømmenes administrative grenser datert til sagakongene, rundt 1000 e.Kr. her i landet (for eksempel Munch 1849). Det ble også antatt at de eldste tingene var allting, der alle frie menn i samfunnet deltok.

På slutten av 1800-tallet ble tanker om diffusjon fremtredende i både arkeologi og språkhistorie, i den forstand at mennesket bare på enkelte steder og under spesielle omstendig- 
heter var innovative, og at idéer og objekter så ble spredt fra en kjerne (Andrén 1997:144). Dette ble særlig viktig for forståelsen av de administrative inndelingsnavnene som fylke, herred, hundare og skipreider. I 1911 hevdet Sven Tunberg at distriktsbetegnelsen herred oppsto i Danmark og derfra spredte seg til Sør-Sverige og Bohuslän (Tunberg 1911). Det hadde da to betydninger, en judisiell - rettslig - og en mer allmenn, det vil si bygd. Denne oppfatningen er fortsatt gyldig i forskningen i dag. Senere har flere vist at det også fantes rettslig inndelte herreder i Sør-Norge (Bull 1931; Indrebø 1935). Diffusjonstankegangen er for det meste forlatt i dag, og en tenker seg at gjenstander og idéer kan ha oppstått flere steder samtidig. Likevel anses det som sannsynlig at visse inndelinger og idéer har spredt seg fra en kjerne, slik flere eksempelvis mener om herredene og skipreidene (Steinnes 1929; Ersland 2000).

Diskusjonen rundt de danske, sørsvenske og sørnorske herredene er lang, og her skal det bare trekkes frem noen få eksempler som har fått betydning for dateringsspørsmålet. I 1965 daterte Kristian Hald flere herreder i Danmark gjennom navnebetydning og navnetypologi på filologisk grunnlag, og hevdet ut fra det at herredene må ha vært ferdig utformet før vikingtiden. Denne tidlige dateringen er senere blitt kritisert, og det hevdes at herredene først kunne ha kommet til under rikssamlingsprosessene $\mathrm{i}$ den siste del av vikingtiden (for eksempel Christensen 1969; Jørgensen 1980:38-39). Også de svenske hundare og hund har omdiskutert alder og betydning (Andersson 1982:54).

På begynnelsen av 1900-tallet ble det utviklet en sterkere kildekritikk av sagaene (Weibull 1911; Koht 1921), og tanken om det fellesgermanske ble derfor ansett som et tysk tankefoster fra 1800-tallet. Dette ledet til at tinginstitusjonen ble mindre studert. Spørsmål om alder ble ofte basert på forholdsvis vidtgående tolkninger av kildematerialet. Som eksempel argumenterte navnegranskeren Gustav Indrebø i 1935 for at tinginstitusjonen går tilbake til 300-600 e.Kr, basert på en datering av én gravhaug som lå i det han anså som et av bygdemidtpunktene for de trønderske fylker (Olsen 1926:263-272; Indrebø 1935:2425, 261-262). Tankegodset om den fellesgermanske kulturen og det germanske ble enda mindre stuerent etter siste krig (Fenger 1991:157).

De siste tiår har igjen flere forskere begynt å arbeide med tingorganisasjonen, og det er nå mulig å studere «fellesgermansk» rett og tankegods, om enn ikke i de samme direkte overførbare former som tidligere (Fenger 1991). Flere forskere har argumentert for at tingsteder hadde mange fysiske og topografiske fellestrekk. Arkeologiske strukturer, som gravhauger, reiste steiner, bautasteiner, kirkesteder, store kokegropfelt og senest også de omdiskuterte ringtunene i Vest- og Nord-Norge, settes nå i forbindelse med tingsteder (for eksempel Brink 2004; Storli 2006; Sanmark og Semple 2013; Svensson 2015a; Ødegaard 2015; Semple mfl. 2019). Nylig har arkeologen Frode Iversen tolket ringtun som representasjonsting på bakgrunn av en korrelasjon mellom antall hus og historiske administrative distrikt, som da trekker funksjonen med delegater fra faste tingkretser betraktelig bakover i tid, til ca. 100 e.Kr. (Iversen 2015a, 2015b, 2017a).

Flere forskere argumenterer for at rettsindikerende navn går igjen i landskapet på og rundt tingsteder. En av de mest fremtredende er filologen Stefan Brink. Han har også arbeidet i skjæringsfeltet til arkeologi. På slutten av 1990-tallet utviklet han sin «central place complex»-teori, tydelig påvirket av den svenske stedsnavnsgranskeren Lars Hellberg (1967, 1975). Han argumenterer på filologisk grunnlag for at visse navn og navneledd som indikerer sentrale funksjoner ofte opptrer sammen, som -tuna, -åker og -voll. Slik kan han vise til 
tingsteder og sentrale plasser i landskapet i jernalderen. Brink daterer disse kompleksene til mellom folkevandringstid og vikingtid, 500-1000 e.Kr. (Brink 1996a). Tolkningene hans forklarer imidlertid i liten grad hvorfor navnene opptrer på samme sted. Det er likevel akseptert at stedsnavn sammen med annet materiale kan belyse sentrale steder og samlingssteder i landskapet, slik flere stedsnavnsgranskere har gjort de senere år (Andersson 1965; Vikstrand 2013; Svensson 2015a, 2015b).

Det er fortsatt ikke noen faste bevis for hvor langt tilbake tingorganisasjonen kan gå i Skandinavia og en må regne med regionale ulikheter. Når det gjelder inndelingsnavn som med sikkerhet kan kobles til tingsteder, som herred, skipreide, fjerding, er stedsnavnsgranskere, som nevnt, ofte forsiktige med å trekke dem lenger tilbake i tid enn vikingtid. Det skyldes at inndelingenes regelbundethet anses som resultat av en sterk regulering, og da er det nærliggende for mange å tenke på kongemakt (for eksempel Indrebø 1935; Christensen 1969; Jørgensen 1980:38-39). Det synes likevel som om det er blitt en konsensus i forskningen for at tingorganisasjonen oppsto engang i eldre jernalder. Dette baseres på komparasjon av ulikt datamateriale, som skriftlige kilder, stedsnavn og smånavn, kartografisk og topografisk materiale og arkeologiske strukturer, som gravhauger, reiste steiner og bautasteiner (Sanmark 2009; Iversen 2013; Sanmark og Semple 2013; Svensson 2015a; Ødegaard 2015; Iversen 2017a; Sanmark 2017). Til tross for dette er det likevel vanskelig å datere tingstedene sikkert.

\section{Metode, definisjoner og analytiske begrep}

For å komme nærmere spørsmålet om tingets alder må en definere tinget som institusjon. For sosiologien Émile Durkheim var en institusjon knyttet til det kollektive (Durkheim 2001 [1894]:45). Det er da underforstått at en del samfunnsmessige utfordringer er av en slik art at de må løses innenfor visse felles rammer hvis samfunnet skal kunne opprettholdes over tid. Her vil en institusjon defineres som en «innretning, organisasjon av en mer samfunnsmessig, ofte offentlig karakter, som bygger på lover, vedtekter eller sedvaner» (Skirbekk 2015; Norsk riksmålsordbok [NRO] 2018). Institusjoner trenger stabilitet og forutsigbarhet for å opprettholdes over tid. Tidligere erfaringer inngår i institusjonens normer og regler, og regulerer så senere atferd og fremgangsmåter (Douglas 1986:48). Det skaper felles tradisjoner som nedfeller seg i handlingsmønstre og leder til at institusjoner, når de først er skapt, kan være vanskelige å endre (Dodgshon 1998:104, 123-124, 131; Foucault 1999 [1974]). Dette gjør at tinget vil inneha visse fellestrekk over tid, som møte til fast tid og sted, som gjør at institusjonen kan studeres over en lang tidsperiode.

Det er vesentlig å identifisere tinget gjennom alle tilgjengelige kilder, og i denne sammenheng særlig ved å knytte spørsmålet om alder til arkeologi og stedsnavn. De to fagtradisjonene er vitenskapelig tett innvevd i hverandre. Arkeologen Bo Gräslund (2010:46) har pekt på at bebyggelsesnavn er en del av det kildematerialet som arkeologer bruker for å skape sitt kunnskapsbilde, som så navnegranskere bruker som sitt referansemateriale, i hva han definerer som et vitenskapelig kretsløp med uskarpe konturer. Både arkeologenes og navnegranskernes tolkninger kan også være basert på analogier til kjente forhold i andre land eller eventuelle skriftlige kilder. Det finnes altså visse metodiske utfordringer som må defineres. I denne sammenhengen er det viktig å skille ut arkeologiske spor som kan representere tinget, og som viser tilbake på at en menneskemasse av en viss størrelse kan ha 
samlet seg på et sted. Når det gjelder stedsnavnsgransking blir det viktig å skille ut kategorier som viser fellesskap. I denne sammenhengen defineres det som navn med et ordinnhold som indikerer samlingsplasser eller navn på distrikt av en type som bør ha hatt en samlingsplass (Andersson 2014:46-50, 67-71; Svensson 2015a:44-45, 58), slike som skipreide, fjerding og herred, og spesielle navnemiljø der tingplassindikerende navn er en av flere forventede bestanddeler (Brink 1996a).

Det må også klargjøres hvordan et tingsted dateres innenfor de to fagtradisjonene, arkeologi og stedsnavnsgransking. Områdene i Nord-Atlanteren er relevante som analogier, da de ble bosatt fra sent 800-tall og fremover, og dermed kan bidra som terminus ante quemdateringer, altså de senest mulige dateringer for når ord og skikker må ha vært i bruk i Skandinavia og herunder særlig på vestlandskysten av Norge. Tinget som fysisk struktur er lite arkeologisk kjent, og en vet i liten grad hvordan et tingsted faktisk så ut. Flere er kjent gjennom stedsnavn, men dersom de ikke støttes av annet materiale er det alltid en fare for at enkelte navn ikke viser til et faktisk ting, slik som for eksempel stedsnavn som inneholder -åker. Dette problemet forsterkes ytterligere ved at den arkeologiske metoden for å datere gjenstander og strukturer i siste ledd ofte bygger på analogier. C14-dateringer og typologi er de vesentligste metodene. De må imidlertid settes inn i en kontekst før de tolkes, og da er analogier ofte av avgjørende betydning. Et problem med datering av for eksempel en gravhaug tolket som et tingsted er hva som egentlig dateres, haugbyggingen eller tingfunksjonen. Ofte har gravhauger tingnavn, slik at et steds tolkning som tingsted støtter seg på stedsnavn som eksempelvis kan ha oppstått som følge av folketro knyttet til spesielle arkeologiske spor, som steinringer, og dermed ikke viser tilbake til et faktisk forhistorisk ting. Slik oppstår igjen faren for ringslutninger.

Datering av stedsnavn gjøres på mange ulike måter. De fleste stedsnavns betydninger kan gi informasjon om en lokalitet og være en kilde til informasjon om eldre perioder, men en viktig forutsetning er at en forstår navnet riktig (navn.ku.dk). En må da vite eldre navneformer, hvilke bestanddeler som inngår i navnet, den navnetypologiske situasjonen, altså om det er rimelig at navnet finnes der, samt utenomspråklige forhold (Nyström 2013:2628). Lydhistorie, bøyningshistoriske dateringer, innhold av låneord eller yngre kristne personnavn kan også brukes (Pamp 1974:22-23), altså former for analogier. Disse språklige dateringskriteriene skisserer opp en stedsnavnskronologi, men den er noe usikker (Vikstrand 2013:11). Det er vanlig å datere stedsnavn etter deres endelse eller etterledd.

For å aldersbestemme bebyggelsesnavn har det vært vanlig å bruke arkeologiske dateringer av bebyggelsen eller fornminner (se Vikstrand 2013:12-13). Tradisjonelt har en derfor ansett at navn ikke kunne være eldre enn fast bosetning og dermed neppe eldre enn jernalderen (Olsen 1915:92-94; Pamp 1974:21-24). I dag er det en trend at de eldste stedsnavnene anses å være eldre og gå tilbake til bronsealderen (for eksempel Brink 1998:314315) eller til og med være enda eldre (se Vikstrand 2013:14 og der anført litteratur). Endringer i synet på jernalderens bebyggelseshistorie som følge av bruken av maskinell flateavdekking og en større forståelse av bosetningenes endringer mellom eldre og yngre jernalder, har ledet forskere, som filologen Per Vikstrand (2013), til å forsøke å revidere begrepsapparatet som har vært anvendt innenfor stedsnavnsforskningen. Han foreslår at en må vurdere «navneetableringen» og «navnetraderingen», det vil si navnets spredning og bruk, og da er det viktig å vurdere jernalderens bebyggelse. Ut fra det foreslår han en ny kronologi for navnetypene. 
I Sverige dateres de eldste bosetningsnavnene som inneholder ulike varianter av -heim, -inge, -løv, -lösa og -vin, til romertid (1-400 e.Kr.). Tilsvarende gjøres i Norge med -heim og -vin-navn. Navneleddene -stad, -bø, -land og -set er i bruk i yngre jernalder i Sverige, men dateres til vikingtid her i landet (Sandnes og Stemshaug 1976; Brink 2008a:58; Vikstrand 2013:97). Det er også store regionale variasjoner i distribusjonen i Norden (Edlund mfl. 2010).

Gjennomgangen viser at både stedsnavn og arkeologi ofte baserer sine tolkninger på hverandres forskningsresultater, og sirkelslutninger kan som nevnt lett oppstå. I tillegg benyttes analogier til andre objekter, steder og tider for å datere gjenstander og navn. Av vesentlig betydning for dateringen er at både gjenstander, strukturer og stedsnavn settes inn i rett kontekst før de tolkes og ses i sammenheng.

Arkeologen Anders Andrén er en som særlig har understreket viktigheten av å studere ting - i betydningen materiell kultur - og tekst i sammenheng, i sin kontekst, fordi begge har inngått i komplekse situasjoner som kan ha endret seg over tid og rom, og til samme tid (Andrén 1997:154). Et mulig tingsted var neppe det samme i bronsealderen som i senmiddelalderen, selv om de kunne dekke basale behov for samhandling. Andrén skiller ut tre analytiske nivåer i slike kontekstuelle analyser av tekst og materiell kultur: det objektbaserte, det integrerte og det tekstbaserte (Andrén 1997:155). I mitt tilfelle tilsvarer det objektbaserte arkeologiske spor etter tingsteder. Det tekstbaserte tilsvarer språklige utsagn og stedsnavn som er oppstått som følge av bruk av et sted som tingsted. Det integrerte perspektivet gjelder situasjoner der de arkeologiske sporene og stedsnavnene utfyller hverandre. Andrén påpeker at for å oppnå best mulig resultater i dialogen mellom kildekategoriene, må en søke etter både likhet og ulikhet, sammenhenger i tid, rom og uttrykk (Andrén 1997:161). Det er tre måter å skape dialog mellom ting og tekst og åpne for nye tolkninger, ifølge Andrén. Det er enten som «samsvar» (korrespondens) og «så mange sammenhenger som mulig» (assosiasjon), men også ved «kontrast», som viser kompleksitet (Andrén 1997:181-182). Hypotetisk kan en fremstille dette som en linje, der spenningen eller økt kunnskap finnes på midten, mellom på den ene siden arkeologi og den andre stedsnavnsforskning (figur 2).

Inspirert av Andréns analytiske begrep kan tilsvarende perspektiver brukes når en skal belyse tingsteders alder. Omskrevet ønsker jeg da å undersøke om arkeologien og stedsnavnsgranskingen bekrefter, utfyller eller motstrider med hverandre. For å kunne benytte de tre begrepene og undersøke dem komparativt vil jeg tilføre ytterligere to analytiske kategorier: det arkeologiske tingstedet og stedsnavnstingstedet. De tre nevnte begrepene kan alle på ulike måter belyse tingets alder: bekrefter og utfyller stedsnavns- og arkeologitingstedet

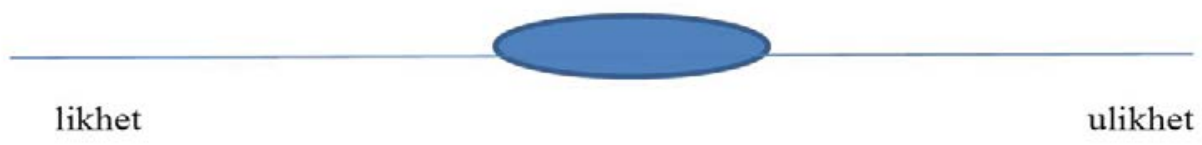

Figur 2. Dialogen mellom ting og tekst kan illustreres som en linje, der spenningen eller økt kunnskap finnes på midten, mellom på den ene siden arkeologi og den andre stedsnavn. Illustrasjon: Marie Ødegaard. 


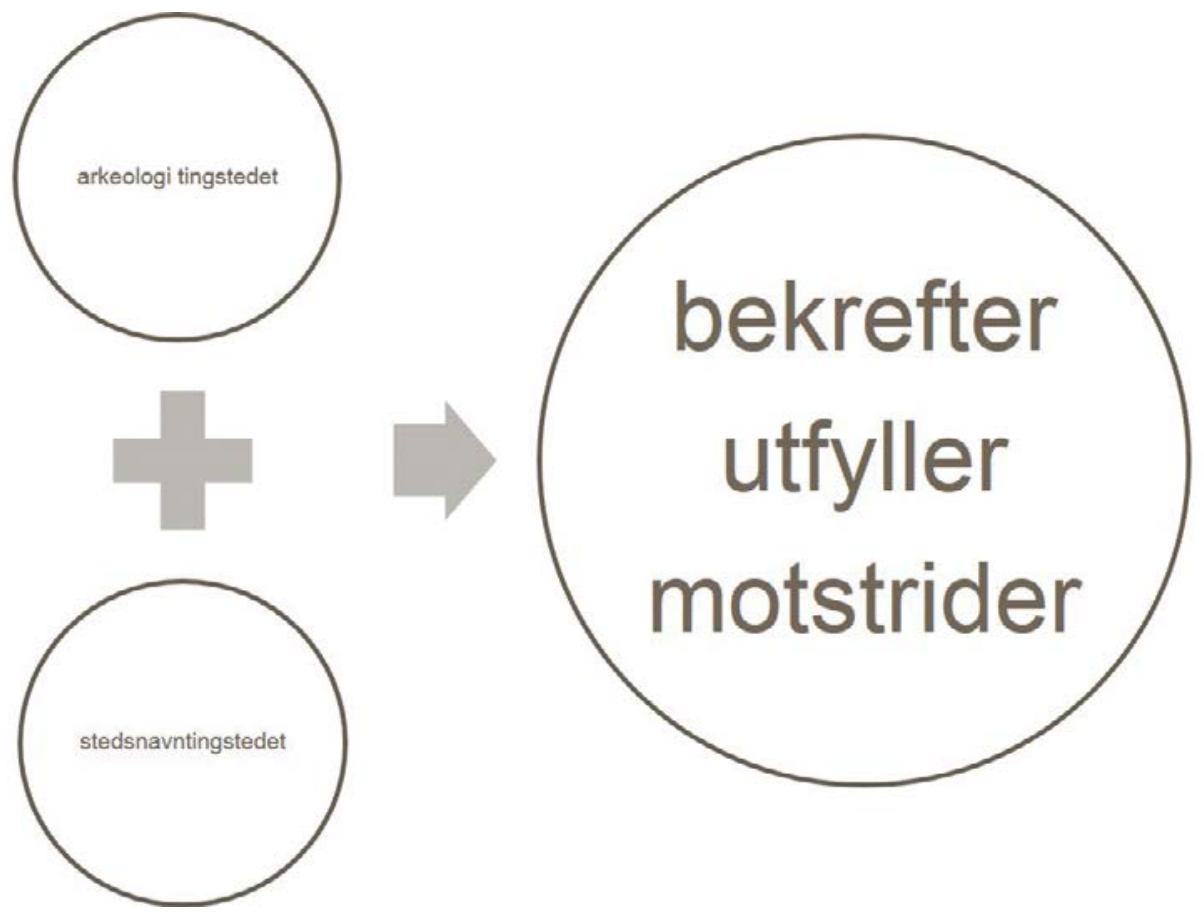

Figur 3. Det arkeologiske tingstedet og stedsnavnstingstedet vil bli undersøkt komparativt, for å vurdere om de bekrefter, utfyller eller motstrider med hverandre. Illustrasjon: Marie Ødegaard.

hverandre, underbygges metoden. De kan da enten direkte eller indirekte med justeringer gi indikasjoner om alder. Motstrider de med hverandre og ikke ligger på samme sted og i henhold til alder, kan det gi indikasjoner om endringer eller eventuelt på metodiske svakheter knyttet til tolkningstradisjonen, som da igjen må undersøkes (figur 3). For å kunne identifisere et stedsnavns- og arkeologitingsted må det først diskuteres hvordan idealtypiske tingsteder ser ut. På den måten kan en nærme seg spørsmålet om alder, og om det er samsvar eller ikke, mer konkret.

\section{Det arkeologiske tingstedet}

Svært få tingsteder er arkeologisk belagt, så det har ingen helt sikre identifikasjonskriterier. Enkelte forskere har hevdet at gravhauger, reiste steiner, bautasteiner og runesteiner er grunnleggende elementer ved vikingtidens tingsteder (Wilson 1994; Brink 2004:209), men det er omdiskutert (for eksempel Ødegaard 2015:344-347). Det finnes riktignok flere eksempler på at fornminner som steinsirkler og gravhauger har vært brukt som tingsteder, som blant annet Gamle Uppsala i Sverige (Sanmark og Semple 2010). Særmerkte topografiske landskapstrekk på steder kjennes også, som Tingvellir på Island som ligger på et høy- 
dedrag mellom to dype, lange kløfter og Tinganes på Færøyene som er knyttet til et stort nes. Eksemplene ovenfor viser at mange av disse stedene gjerne har ting-navn. Eldste datering av bruken av en gravhaug som et tingsted er fra 1300-tallet i Norden og viser at tradisjonen minst er middelalderlig (Jensen 2002:157-159). Eldre eksempler kjennes fra England og går tilbake til 1000-tallet (Dalsberg og Sørensen 1979:75). Selv om en gravhaug kan dateres til vikingtid, kan stedet som tingsted være mye yngre. Det er derfor vanskelig å skille mellom monumenter som faktisk har vært brukt som tingsteder og de som er blitt tilskrevet slik status senere. Dermed er det vanskelig å datere stedene presist.

Frostatingsloven forutsetter at det skulle lages vébond på tingene, som er en ring av hasselkjepper med en streng imellom (G 91; F I 2). Det kjennes enkelte arkeologiske steder som er tolket som mulige spor etter vebånd. På Lilla Ullevi i søndre Uppland, datert til 600750 e.Kr., er det funnet spor etter et innhegnet område av stolpehull og ildsteder, og dessuten mange jernringer og amulettringer (Bäck og Stenholm 2012). Ringer (baugr, hringr) er sterkt symbolladet (Brink 1996b:48). Noen kan ha vært edsringer (Habbe 2005:145), brukt når en inngikk avtaler på tinget. Stedene fremstår som kultsteder, men er mer usikre som tingsteder.

Fra Sverige kjennes ett firkantet vikingtidstingsted, Arkels tingstad i Uppland, som hadde steiner i firkant og en stein i midten av ringen (figur 4). Ytterligere noen belegg for firkantete tingsteder kjennes, men fra mye yngre kilder. Fra 1600-tallets Småland og Skåne kjennes firkantete innhegninger av stokker, omtalt som «tingstockar» (Hyltén-Cavallius 1868:323-324; jf. Svensson 2015a:148). Beskrivelser fra 1700-tallet i Danmark kaller dem som sitter på benkene for «stokkemenn» (Haderslev byrett fra 1292, art. 24, DGK I, s. 272, referanse i Schledermann 1982:375). Skånelagen fra tidlig 1200-tall vitner om at dette kan gå lenger tilbake i tid, da det inneholder uttrykket «tingstock och stocknämnd» (stockänefnd) (Nordén 1938:290). At det ble satt opp benker i kvadrat under åpen himmel, er også kjent fra danske byting på 1200-tallet (Schledermann 1982:375). Det finnes imidlertid ingen flere sikre belegg i Skandinavia for at tingsteder skal ha vært firkantete.

De seneste tiår har det dukket opp flere store, såkalte spesialiserte kokegropfelt, særlig i Nord-Tyskland, Sør-Skandinavia og Sørøst-Norge. I Norge er de hovedsakelig datert til romertid og folkevandringstid, det vil si fra rundt Kristi fødsel til 600 e.Kr., mens lenger sør går de lenger tilbake i tid, fra sen bronsealder til eldre jernalder, altså kan hende tilbake til ca. 1100 f.Kr. (Henriksen 1999:90-92, 112; Martens 2005:37). Gropfeltenes funksjoner - ut over matlaging - er omdiskutert (for eksempel Narmo 1996; Gustafson mfl. 2005). Det er enighet om at det er spor etter store periodiske samlinger, mens enkelte mener de hadde politiske og rettslige funksjoner (Gjerpe 2001; Skre 2007; Ødegaard 2015, 2018). Det meg bekjent største feltet, Rønninge Søgård på Øst-Fyn, kan ha hatt hele 1600 kokegroper (Henriksen 2005:83).

Det største feltet her i landet er funnet på Lunde i Vestfold, nær Tjølling kirke, og hadde anslagsvis 1000 groper (Ødegaard 2015:301-318,2019). Feltet ble arkeologisk undersøkt i 2010. Det spesielle der er at stedsnavnet er tolket som tingstedsindikasjon, men datert til perioden etter at feltet gikk ut av bruk. Et tilsvarende kokegropfelt er kjent lenger nord, på Bommestad. Navnet Bommestad er skrevet Bundingsstadum i dativform i Biskop Eysteins jordebok fra slutten av 1300-tallet, og er rekonstruert og tolket som Bundingsstaðir og Bóndpingstaðir, «bondetingsted» (NG VI:342). Det må understrekes at det kan være vanskelig å sikkert definere alle kokegropfelt som tingsteder koblet til tinginstitusjonen uten tilsvarende navn. I nåværende Norge er det kjent elleve store kokegropfelt med mer enn 100 kokegroper. Av dem kan ti ligge på steder som senere har hatt tingsted og middel- 


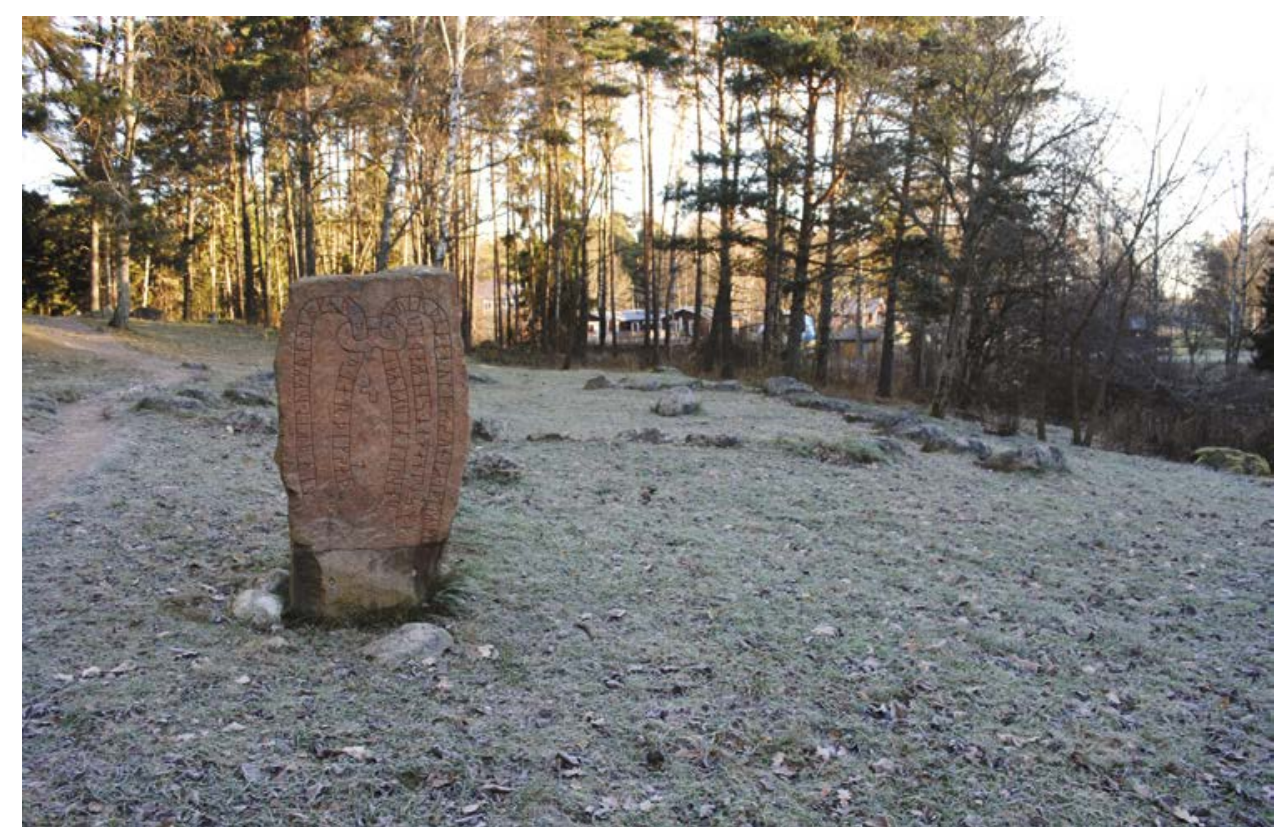

Figur 4. Arkels tingstad i Uppland, Sverige, er et av få eksempler på firkantete tingsteder. Foto: Marie Ødegaard.

alderkirke, som indikerer en fortsatt samling på disse stedene etter at kokegropfeltene går ut av bruk (Ødegaard i trykk). Flere av dem, som Lunde og Bommestad, men også Guåker i Hedmark og Hoffsvangen på Østre Toten, er funnet nær plasser med stedsnavn koblet til tinginstitusjonen, og kan kobles til administrative inndelinger i herred. De har belagt senere tingsted og middelalderkirke, som sannsynliggjør at store kokegropfelt kan ha vært tingsteder. Muligens går de tilbake til førromersk jernalder enkelte steder her i landet (Ødegaard i trykk).

Ringtun, en samling hustufter beliggende rundt en oval halvsirkelformet åpen plass (Johansen og Søbstad 1978:55), er tolket som tingsteder de siste år. Omtrent 30 slike kjennes i Vest- og Nord-Norge, datert fra ca. 100 til omkring 900 e.Kr. (Olsen 2003; Storli 2006; Iversen 2015a:101). Nylig har disse som nevnt vært tolket som representasjonsting, der delegater fra distriktene rundt møttes. Til forskjell fra kokegropfeltene viser flere ringtun kontinuitet mellom eldre og yngre jernalder, rundt 550 e.Kr., da hovedbruken av kokegroper gikk ut av bruk. En annen og betraktelig større forskjell med tanke på tinginstitusjonen er at ringtunene kan relatere seg til senere administrative områder på ulike nivåer, som skipreider og fjerdinger, og maktsentraliseringsprosesser. Iversen har argumentert for at det var en korrelasjon mellom antall hus på anleggene og antall tilknyttede rettsområder kjent fra senmiddelalderen og tidlig moderne tid. På den måten kan en trekke representasjonsting knyttet til faste distrikter lenger bakover i tid enn det som før var mulig.

Som eksempel kan en se på ringtunet Øygarden, som lå sentralt i Ryfylke i Rogaland. Ryfylke hadde ti skipreider i tidlig middelalder, og det var like mange hus på ringtunet der 
(Iversen 2015a:106). Liknende sammenhenger skal finnes på anlegg i Rogaland og Hålogaland. Dateringer sannsynliggjør også at anlegg avløste hverandre. Dermed kan en skille ut ulike nivåer i organisering, slik at enkelte større anlegg tolkes på et høyere nivå, eksempelvis Øysund og Gimsøy i Hålogaland. Ifølge Iversen kan disse tolkes som «flerfylkesting». Ringtun kjennes derimot bare fra Vest- og Nord-Norge, noe som i seg selv åpner interessante spørsmål. Tingstedene på Island hadde også boder, men de skiller seg fra ringtunene ved å ha en mer uregelmessig utforming. De opptrer også først mellom 950 og 1200-tallet (Olsen 2003; Storli 2006; Vésteinsson 2013:113; Iversen 2015a:2). På Island var det først flere lokale tingsteder ifølge Landnåmabok. Senere, i 930 e.Kr., ble alltinget på Tingvellir opprettet for hele Island. Her er altså ting på ulike nivå, uten noen overregional kongemakt før 1262 (Stefánsson 1984; Byock 2001; Mehler 2015).

Enda lenger tilbake i tid går helleristningsfelt, spor av store samlinger fra bronsealderen i fortrinnsvis kyststrøk i Sør-Norge og Sør-Skandinavia, fra ca. 1500-500 f.Kr., men ikke sikre som tingsteder. Tilsvarende må en si om de enda eldre, neolittiske befestede kultplassene i Sør-Skandinavia, såkalte Sarupanlegg. De er datert til ca. 4000-3200 f.Kr. (Andersen 2004), og ligger ved kysten, nær elver og elveutløp. Ett slikt felt er kjent i Norge, fra Hamresanden i Vest-Agder. Stedet er tolket som et rituelt sted der mat for mange mennesker ble gjort i stand - kanskje for spesielle, årlige begivenheter (Glørstad og Solheim 2015:148). Offersteder, for eksempel i myrer, forutsetter også steder hvor flere mennesker har samlet seg for å foreta rituelle nedleggelser. En korrespondanse mellom offerplasser og stedsnavn som indikerer tingplasser er påvist i Sverige, blant annet i Kvärrestad. Der ble det gjort funn av et hestekranium datert til sen vikingtid med en senneolittisk flintdolk i pannen nær marknavnet Tingsmaden, som indikerer et tingsted (Svensson 2015a:224). Flere andre arkeologiske kategorier kan indikere ulike samlinger av mennesker og hvor rettslige forhold, forsvar og så videre, kan ha vært en del, slik som store leidangsnaust og bygdeborger. Selv om bygging av dem kan ha vært besluttet på tingsteder, har lokalitetene neppe hatt funksjoner som tingsteder. Kanskje må en skille ut to arkeologiske tingstedsaldre, den første sikre identifikasjonen av tinginstitusjonen i Norden rundt 900-1000 e.Kr, og en eldre med mer usikre spor, i form av spesialiserte kokegropfelt og ringtun, som også synes å ha vært store fellesarenaer og former for samhandling. Senere i artikkelen vil den siste kategorien, ringtun og kokegropfelt, bli studert for å undersøke om disse sporene etter samlinger kan representere tinginstitusjonen i tidlig eldre jernalder. Tross ulik alder og utforming, der hoveddelen av de store kokegropfeltene som nevnt gikk ut av bruk rundt $600 \mathrm{e} . \mathrm{Kr}$., vedvarte ringtunene til 900-tallet og kan være mulige spor av representasjonsting. De har også ulik distribusjon, med ringtun i Vest- og Nord-Norge og kanskje også på Island, og kokegropfelt i SørSkandinavia og Sørøst-Norge.

\section{Stedsnavnstingstedet}

Når det gjelder stedsnavnstingstedet er ordet ting, gammelnorsk ping, kjent i alle germanske språk (binga- n.), i betydningen «møte, særlig rettsmøte, (retts)sak, rettsforhandlinger, rettsinstans» og også mer generelt «sak, ting, eiendel» (Bjorvand og Lindeman 2000:940). Ordet sammenstilles som regel med det gotiske peihs n. «tid». Det er uklart hva de ubelagte, men antatt eldre, germanske formene av ordet stammer fra - tid eller møte (Bjorvand og Lindeman 2000:940). Den svenske stedsnavnsforskeren Ola Svensson (2015a) understreker at 
ordet har en fonetisk sett stabil oppbygning som ikke synes å ha endret seg særlig så lenge ordet er kjent i nordiske språk. Det eldste indirekte belegget for ordet ting i de germanske språk er fra en steinsøyle i Nord-England, skrevet Thincso og tolket som en gud som skulle beskytte tinget, datert til 200-300-tallet e.Kr. (Wenkus 1984:443; Iversen 2013:10-11).

I Norden er ordet først belagt på svenske runesteiner fra 1000-tallet. Når ordet opptrer i kildene er det sammensatt med andre navneledd. Ofte er de smånavn, altså navn på åker og eng, og knyttet til fornminner. Langt mer sjelden opptrer de som gårdsnavn. Navn med -haug som etterledd er ofte koblet til gravhauger og brukt sekundært som tingsteder i Skandinavia. Enkelte tinghauger er antatt bygd som tingsteder, som Tinghaugen ved Gamle Uppsala (figur 5). Etterleddet -voll forekommer også ofte på tingsteder (Hedblom 1958:7576; Brink 1990:470). Tingvoll pingvollr betyr «lovlig tingsted», og har mange paralleller i Norden, med Pingvellir på Island som det mest kjente (Brink 2003:64), angivelig som nevnt fra 930 e.Kr. Tinghaug og Tingvoll kan begge dateres til siste del av vikingtiden, og viser en nær kobling mellom tinghauger og tingmøter på fremtredende hauger og sletter (Brink 2003:64). At disse navnene opptrer på Island, Vesterhavsøyene og i Danelagen indikerer at de må ha vært i bruk da nordboerne bosatte seg der i vikingtid, og følgelig må være eldre (Pantos 2004; Semple 2004). Et problem er at de enkelte stedsnavn kan ha blitt dannet alt fra eldre jernalder og opp til moderne tid, og det gjør det vanskelig å bruke dem til å datere

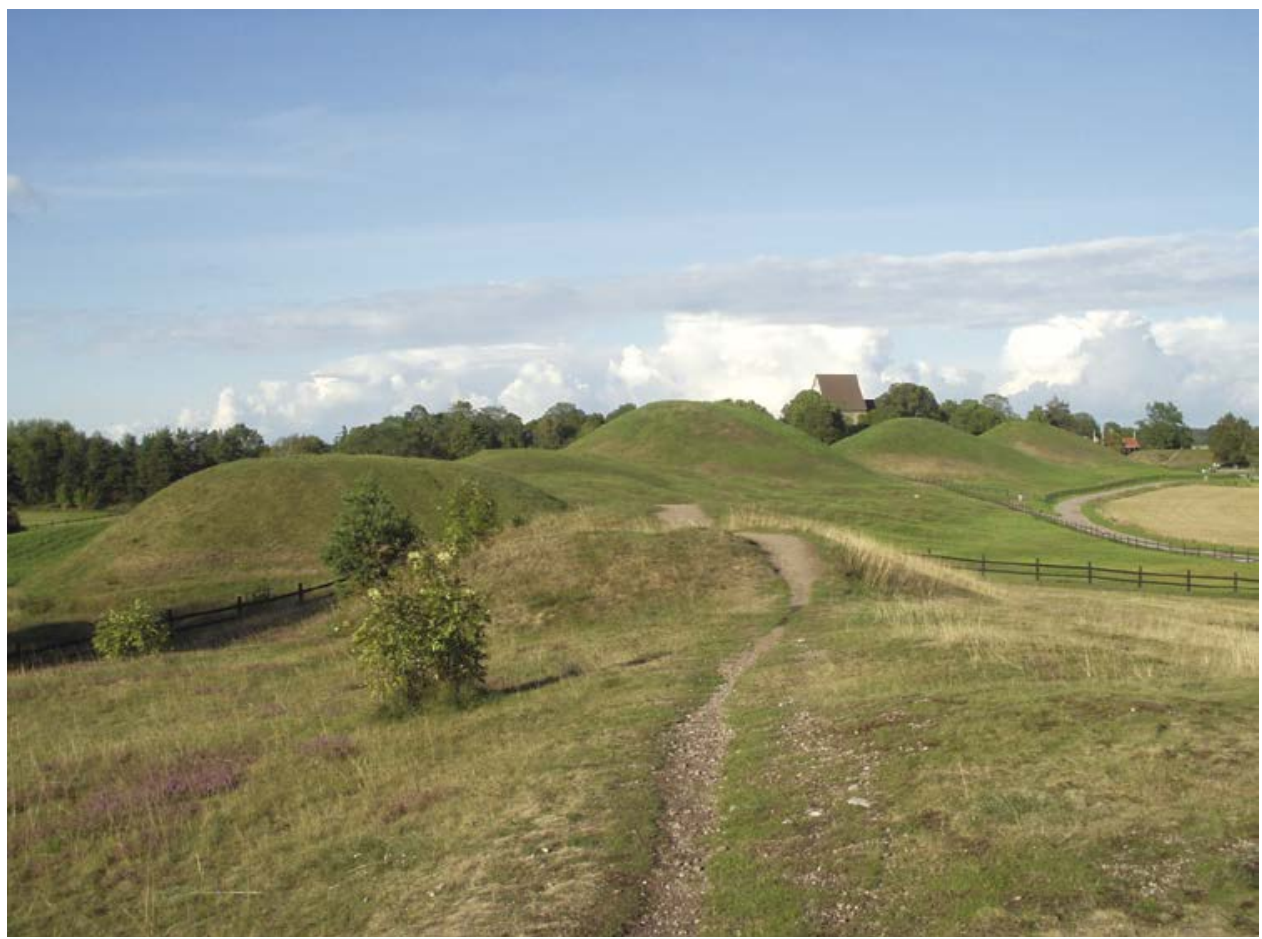

Figur 5. Gamle Uppsala, Sverige, med sine store gravhauger inklusive den såkalte Tinghaugen som kan skimtes til høyre og middelalderkirken i bakgrunnen. Foto: Marie Ødegaard. 
de enkelte tingsteder. Et annet problem er at navnene også kan referere til «haugen på vei til tingstedet» (Dalberg og Sørensen 1979; Svensson 2015b). Med tanke på den usikre bakre datering av navn som refererer til gravhaug som tingsted, anses stedsnavn som fellesnavnet -tingvoll som den sikreste stedsnavnsindikasjonen på et tingsted som har eksistert under vikingtiden og tidligere.

Flere runesteiner og runeinnskrifter i Sverige er datert fra 800- til 1100-tallet med innskrifter koblet til tingsteder og rettsfellesskap. Forsaringen fra Hälsingland i Sverige inneholder ordet vi av vé n. som betyr «helligdom» (Fritzner 1896:882). Den er datert til 800-tallet. Ringen inneholder den eldste kjente rettsregel fra Skandinavia (Ruthström 1990:41-56; Brink 2003:67-68; Sundqvist 2007:164-185). Det finnes flere beskrivelser av et vi som en hellig, avgrenset plass for rettslige handlinger i vikingtidens Skandinavia. Som nevnt er åtte slike lokaliteter de senere år blitt arkeologisk undersøkt i Midt-Sverige. Dateringene spenner i tid fra ca. 400 f.Kr. til 1000 e.Kr. (Bäck og Stenholm 2012:112-113 med referanser). Et problem er imidlertid at en ikke kan være sikker på om dette virkelig er tingplasser og ikke bare helligsteder, selv om skillet neppe var så skarpt.

De eldste territoriene i Skandinavia var trolig de såkalte landskap, som i forhistorisk tid og middelalder ble kalt for land. Selv om de nok har hatt en eldre betydning av jordbruksland, fikk de senere en mer regional betydning. Førsteleddet viser ofte til en stamme eller et folk, for eksempel grenir i Grenland (Brink 2008b:98-99). Noen landskap kan være eldre, og går tilbake på eponymene rike, altså noe som har fått navn etter en person, som Romerike og Ranrike (Andersson 1979). Eldste sikre belegg for land er fra runeinnskrifter fra 1000-tallet. Vesentlig er imidlertid at betegnelsen land også ble brukt av klassiske forfattere, som Tacitus i 98 e.Kr. og Jordanes i 551 e.Kr., men da i betydningen navnet på folk som geografisk identifikasjon, altså en form for stammenavn (Brink 2008b:100). Mange av disse landskapene er senere kjent som lovområder, slik som Hälsingeloven for hælsingarne i Hälsingland, hvor den nevnte Forsaringen ble funnet. Ifølge Brink må land som distriktsbetegnelse ha eksistert godt før vikingtid, men trolig ikke før romertid. Han argumenterer for at en ofte kan spore et fast, felles tingsted i disse landene (Brink 2008b:96 med referanser, 100, 106). En kan likevel ikke vite når dette tingstedet oppsto og hvor fast geografisk disse områdene var. Det gjør det noe vanskelig å bruke dem til sikkert å datere tinginstitusjonen.

En distriktsinndeling som fikk stor betydning i Norden i fra vikingtiden og ut gjennom middelalderen, er norske skipreider (figur 6), det svenske skeppslaget og dansk skipan f., som viser til distrikt som skal stille med et leidangsskip til landets forsvar (Fritzner 1896:341). Danske skipan er belagt på runer på 1000-tallet (Andersson 2014:10-11). I tidlig middelalder er skipreiden kjent som tingkrets, og var det trolig også tidligere. De tre fornnordiske ordene skip, skipa og skipan og selve leidangsorganisasjonen er omdiskutert (Andersson 2014:11-12). Ettersom det er enighet om at disse inndelingene erstattet eldre inndelinger i herred, må de være yngre, fra vikingtid eller tidlig middelalder.

En annen administrativ og særlig omdiskutert inndeling er de før nevnte sør-skandinaviske og sør-norske herred/härad og de svenske hundare og eldre hund. Herred og hundare er nevnt i skriftlige kilder rundt 1000-tallet. Fra Oslofjord-området og deler av Danmark er det kjent at herredet var underinndelt i flere mindre tingdistrikter (Den Jyske Lov II:1; Indrebø 1935). I dag er det enighet om at førsteleddet i ordene herred/härad kommer av hær, «krigerskare», og etterleddet av råd i betydningen «makt», og er tolket som «av en høvding som har hatt makt over en bevæpnet skare» (Andersson 1965, 1999, 2000). Den aktuelle 


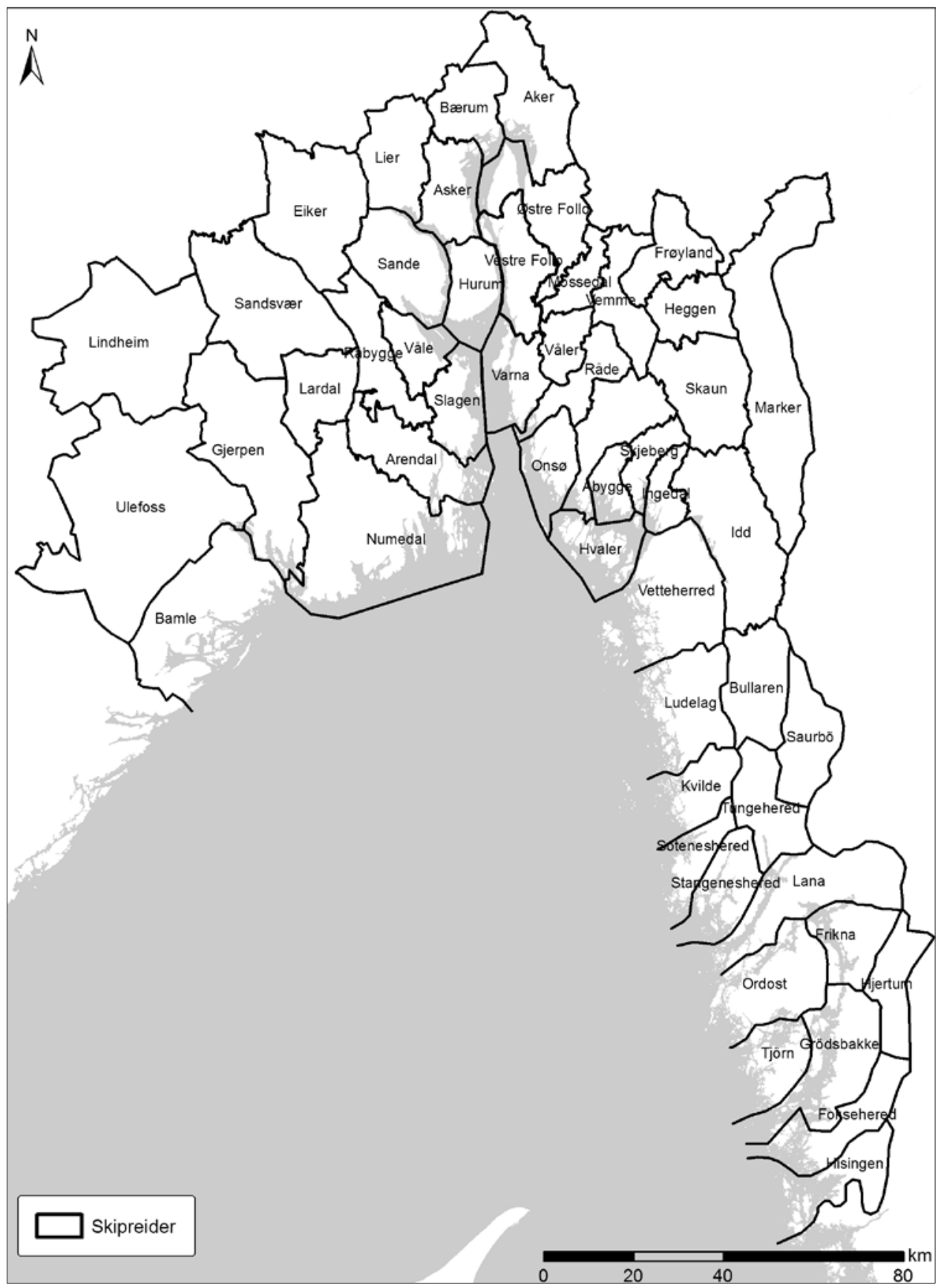

Figur 6. Rekonstruerte skipreider i Borgartingslagen. Kartgrunnlag: Statens kartverk. Tillatelsesnummer NE12000-150408SAS. Illustrasjon: Marie Ødegaard. 
sammenheng de to ordene «råd» og «makt» har inngått i, er imidlertid mer omdiskutert og uklar (se Svensson 2015a:27-34 og der anført litteratur). Hund og hundare kommer av det germanske regneordet *hunda $\mathrm{n}$. av «hundre» (Andersson 1982:54) og er blitt forklart som «styrke på hundre mann», og viser til det kollektiv som skulle avses til leidangen. Disse distriktene skal ha hatt et felles tingsted. De fleste forskere synes å mene at herred og hundare tilhører sen vikingtid (Tunberg 1911; Bull 1920; Christensen 1969; Jørgensen 1980:3839), mens andre som nevnt mener at de må være eldre (Hald 1980 [1961]:497). Hundaren ble i løpet av vikingtiden lagt over hund-distriktene i Mälar-landskapet i Sverige. Ettersom hundare dateres til sen vikingtid, må hund være eldre, fra tidlig vikingtid eller før (Strauch 2001:186 med referanser). Thorsten Andersson avviser en så sen datering av både hund og hundare. Han mener at de kan være eldre enn 700-tallet siden Tacitus nevner germanske grupper på hundre menn. Hundare har også motstykke i de kontinentale (forntyske) begrepene huntari og hunderi, i betydningen «krigerskare, en skare menn, en hop av mennesker» (Tunberg 1911:43; Andersson 1999:6), kjent alt på 700-tallet. Her har det også vært påpekt at det svenske hund indirekte kan vise til personbenevnelsen hunn og hunne på kontinentet, og bety «ledere for hundre menn» tilsvarende eksempelvis det frankiske centenarius på 500-tallet (Andersson 1999:6, 2014), som direkte oversatt betyr «bestående av hundre» og «hundrefold» (Lewis og Short 1879).

Området rundt Mälaren kaltes i forhistorisk tid for Svetjud, fsv. Svethiud. Navnet er sammensatt av folkeslagsbetegnelsen svear og et gammelt ord for folk, thiudh (Andersson 2004:5). Jordanes nevner folkegruppen Suetidi i 551 e.Kr. Tacitus beskriver dem i 98 e.Kr. som et sjøfarerfolk som er mektige gjennom menn, våpen og skip (kap. 44). Andersson påpeker at det ikke kan være tilfeldig at svearne nevnes som sjøkrigsfolk, og hadde en forhistorisk inndeling bygd på skip og mannskap, men forskere er fortsatt forsiktige med å tolke alderen til hund-organisasjonen av dette (Andersson 2014:14). Men når det nettopp nevnes av Tacitus, må en vel kunne forvente at inndelingen kan gå langt tilbake i tid, om enn kanskje ikke like fast geografisk (Andersson 1979). Noe sikkert eldre enn 700-800-tallet er det likevel vanskelig å komme.

Det har vært vanlig blant studier av stedsnavn å vurdere stedenes topografiske og arkeologiske kontekster, for eksempel for å få en antagelse om steders eller samlingsplassers alder (Andersson 1965; Brink 1998; Vikstrand 2013; Svensson 2015a; Vikstrand 2015). Flere slike studier har påvist en klar kobling mellom navn på administrative distrikt, som herred og tingsteder (Andersson 1965; Vikstrand 2001:375; Svensson 2015a; Vikstrand 2015). Dette er også påvist innenfor historisk og arkeologisk forskning (Seip 1934:85; Indrebø 1935; Moseng 1994; Baker og Brookes 2013; Ødegaard 2013, 2015). Typisk i disse sammenhenger er at tingstedene viser til en jordeiendom, et topografisk landskapselement og en bebyggelse med et navn som korresponderer med et distriktsnavn, som for eksempel Harthaker i Harjagers härad (Svensson 2015a:189-202). Felles for disse studiene er at de er utført av både stedsnavnforskere, historikere og arkeologer der en har forent middelalderske administrative forhold, belyst med historisk kildemateriale, og arkeologiske iakttagelser fra onomastisk belagte tingsteder. Jordeiendom- og naturnavn på -ting og -galge kjennetegner ofte disse stedene (Andersson 1965; Svensson 2015a), mens i Norge vil galgesteder sjelden inngå i disse sammenhengene siden de som regel finnes ved grenser og utkant av bebyggelser (Ødegaard 2015:332-336). 
I Sverige er de typiske stedsnavntingstedene - Rum, Löt, Bara, Torn, Hårdåker, Rönnebjär, Lög og så videre - ofte umulig å datere onomastisk, men disse navnene har ofte gitt navn til selve rettskretsene (Andersson 1965; Vikstrand 2013; Svensson 2015a; Vikstrand 2015). Hvordan en skal datere stedene er da avhengig av hvordan en tolker alderen til rettskretsene og distriktene mer generelt, og resultatet kan være avhengig av hvordan en ser på bosetningsutviklingen og dens eventuelle kontinuitet (Andersson 1965; Hald 1980 [1961]:497; Jørgensen 1980; Andersson 1982, 1999; Brink 2008a; Vikstrand 2013; Svensson 2015a). Til tross for sammenkoblingen av arkeologi, stedsnavn og administrative grenser er det likevel vanskelig på sikkert grunnlag å datere tingstedenes alder helt konkret, og en er avhengig av hverandres kildemateriale for å kunne datere tingstedene og rettskretsene.

Gjennomgangen av stedsnavnstingstedet viser også at det her finnes mange sikre belegg for stedsnavn knyttet til ting og territorier fra vikingtid og fremover. Eldst er kanskje stedsnavnselementet -land, men siden det er usikkert koblet til tingsteder ved midten av 500-tallet, er de mest sikre dateringer av stedsnavn som kan belyse tinginstitusjonens alder, mer konkret tingvoll, som har vært produktiv under vikingtid, og inndelingsnavnene hundare/hund, som anslås å kunne strekke seg tilbake til 700-tallet. Jeg anser da disse, om enn av litt ulik karakter, som representanter for stedsnavnstingstedet.

\section{Case-studier - samsvar eller ikke?}

Denne gjennomgangen av det arkeologiske tingstedet og stedsnavnstingstedet viser at en kan være sikker på at en tinginstitusjon eksisterte i vikingtid i Skandinavia. Her skal det derfor gjøres forsøk på å spore tinget som institusjon lenger bakover i tid ved å bruke de to tidligere etablerte analytiske kategoriene, til tross for at de er ganske ulike. Det er her antatt at tingvoll og inndelingsnavnene hundare og hund på et relativt sikkert grunnlag kan trekke stedsnavnstingstedet lengst tilbake i tid. Det arkeologiske tingstedet synes foreløpig å gå lenger bakover i tid, til rundt Kristi fødsel eller kan hende før. Jeg ønsker da å sette disse to kategoriene, det arkeologiske tingstedet og stedsnavnstingstedet, opp mot de tre analytiske begrepene ved tre case-studier, for å se om de bekrefter, utfyller eller motstrider med hverandre.

Bekrefter: Et eksempel på at det arkeologiske og stedsnavnstingstedet faller sammen, er på ringtunet Dysjane på Jæren, datert til 200-600 e.Kr. Her kjennes stedsnavnet Tinghaug, som er en naturlig bakke på det høyeste punktet på Låg-Jæren, 102 moh. Her skal tingstedet for Midt-Jæren ha ligget (Iversen 2015a). En kan selvsagt ikke vite hvor gammelt navnet er, men det kan altså gå tilbake til før vikingtiden. Der er det også funnet 16 gullgubber, små gullblikk, datert til merovingertid, 550-800 e.Kr., og to gravhauger fra henholdsvis folkevandringstid og vikingtid ligger på høyden, som bekrefter at stedet ble ansett som viktig over en lang periode (Kristoffersen mfl. 2014; Lillehammer 2014). Her bekrefter både det arkeologiske tingstedet og stedsnavnstingstedet hverandre, og dateringene av dem faller, $\mathrm{i}$ hvert fall relativt, godt sammen.

Utfyller: I 2010 foretok forskningsprosjektet The Assembly Project og Kulturhistorisk museum, Universitetet i Oslo, i samarbeid med LBI-prosjektet bestående av Ludwig Bolzmann Institute for Archaeological Prospection and Virtual Archaeology (LBI), Norsk Institutt for Kulturminneforskning og Vestfold fylkeskommune, en utgravning på det før nevnte kokegropfeltet på Lunde nær Tjølling i Vestfold med ca. 1000 kokegroper (figur 7) 


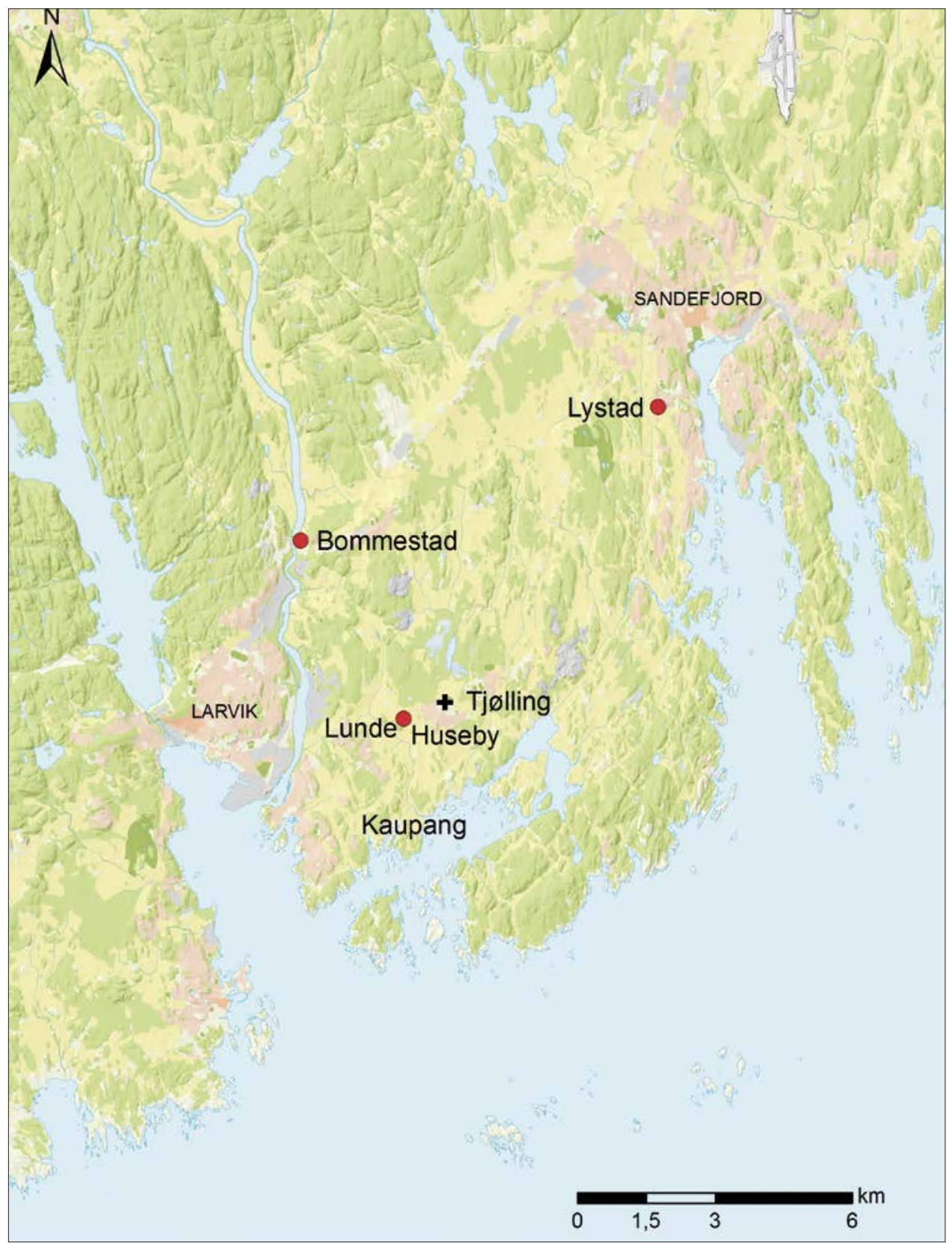

Figur 7. Kokegropfeltet på Lunde med ncerområdet, vikingtidshandelsplassen Kaupang, vikingtidshallen på Huseby og middelalderkirken ved Tjølling. Her ses også lokaliseringen av kokegropfeltene på Bommestad og Lystad. Kartgrunnlag: Statens kartverk. Tillatelsesnummer NE12000-150408SAS. Illustrasjon: Marie Ødegaard. 
(Ødegaard 2015). Dateringene viser et langt tidsspenn fra ca. 400 f.Kr. til 600 e.Kr. Bruken av feltet opphører rundt $600 \mathrm{e} . \mathrm{Kr}$, som er vanlig på flere kokegropfelt her i landet (Gustafson mfl. 2005; Ødegaard 2019). Nærområdet til kokegropfeltet er interessant i sammenheng med mulige tingfunksjoner og som et tidlig rettsområde. Lunde ligger nær vikingtidshandelsplassen Kaupang og sentralplassen Skiringssal fra eldre jernalder (Skre 2007:223, 440 445). Tjølling middelalderkirke ligger ca. $1 \mathrm{~km}$ nordøst for Lunde, en spesielt stor kirke som kan ha hatt funksjoner for et noe større omland (Brendalsmo 2003; Skre 2007:391-392; Ødegaard 2015:308). Navnet Tjølling, avledet av et norrønt Pjóðalyng, der førsteleddet pjóð f. «folk» sammensatt med markslagsbetegnelsen lyng $\mathrm{n}$. er tolket som et regionalt tingsted (Storm 1901:227). Et diplom viser også at det ble holdt et regionalt tingmøte her i 1557 (DN I, nr 1118). Ved kirken kjennes også navnet Vollen av -vollr, men uten eldre navneformer er det vanskelig å vite sikkert om navnet refererer til en tingvoll og et eldre samlingssted, selv om det er tenkelig at det refererer til selve lyngheden, Tjølling (Brink 2007:63). Navnet Tjølling er vanskelig å datere. Gustav Storm daterer navnet til eldre jernalder, mens Brink mener at det på grunn av det formodede vikingtidsnavnemiljøet det inngår i, med Huseby og Kaupang, heller bør dateres til yngre jernalder (Storm 1901:227; Brink 2007:63). Som nevnt ser bruken av kokegropfeltet ut til å opphøre rundt 600 e.Kr., men navnemiljøet rundt Tjølling indikerer en videre bruk som tings- og samlingssted for et større omland i perioden etter kokegropfeltets brukstid. En kan selvsagt ikke være helt sikker på kontinuitet mellom periodene, men det sannsynliggjøres av det tilsvarende feltet på Bommestad (Bóndpingstaðir) - bondetingstedet - lenger nord (Ødegaard 2015:301318; Ødegaard i trykk).

Motstrider: Et eksempel på at det arkeologiske og stedsnavnstingstedet gir motstridende opplysninger, er et kokegropfelt som ligger på gården Lystad i Sandefjord i Vestfold, om lag $800 \mathrm{~m}$ øst for fjorden, med 106 kokegroper datert til mellom 50 f.Kr. og 445 e.Kr. (Helliksen 2009). Navnet har ingen eldre belegg enn Liszestadt fra 1528 (NRJ IV:127), tolket av Olaf Rygh som mulig Lýsustaðir der førsteleddet ljós, lys, er tolket som av elvenavnet Lýsa, «den lyse eller den lysende» (NG VI:277) med suffikset -stad, som indikerer at navnet kan gå tilbake til vikingtid (Sandnes og Stemshaug 1976). Navnet har dermed ingen tydelig kobling til tingsted, og kan følgelig ikke benyttes for å gi indikasjoner på samlinger. Her finnes heller ingen senere indikasjoner på samlinger, slike som middelalderkirke, arkeologiske strukturer og navn som kan gjenfinnes i den administrative strukturen, og som kan vise til et tingsted her. Dette eksempelet viser at stedsnavnet og de arkeologiske kildene ikke faller sammen, som i denne sammenheng gir indikasjoner på endringer, der kokegropfeltet og samlingsstedet kan ha gått ut av bruk eller blitt flyttet rundt midten av 400-tallet e.Kr.

\section{Diskusjon om alder/kontekst}

Det er tilsynelatende et gap i tid mellom stedsnavn og arkeologiske spor som kan vitne om tingets alder, men gjennomgangen viser også vanskelighetene ved å datere tinget uten å trekke veksler på en kombinasjon av kilder. I onomastiske studier som tar opp tingstedsindikerende stedsnavn, er det få eksempler der onomastikken ikke kan bekrefte, bekreftes av eller komplementerer/komplementeres av fornlevninger (for eksempel Andersson 1965; Brink 2004; Vikstrand 2013; Svensson 2015a, 2015b; Vikstrand 2015). Slik er det også for flere arkeologiske studier av tingsteder, kokegropfelt og ringtun der stedsnavn er viktig (for 
eksempel Meaney 1997; Pantos 2004; Sanmark 2009; Baker og Brookes 2015; Iversen 2015a, 2015b; Ødegaard 2015; Iversen 2017a; Ødegaard i trykk). I de tilfellene hvor stedsnavnene og de arkeologiske kildene ikke sammenfaller, er det mulig det har skjedd endringer, uten at det kan spores konkret når og hvorfor. I realiteten bygger stedsnavnsforskning og arkeologi i stor grad på hverandres kilder, og benytter seg av de samme metoder, slik det ble påpekt innledningsvis (Gräslund 2010:46).

En ting som er avgjørende for tolkningen innenfor både arkeologi og stedsnavnsforskning er dermed hvor langt tilbake en ser for seg at bosetning, navn og rettslige inndelinger kan ha hatt kontinuitet. Det er innenfor arkeologisk forskning påpekt at det skjedde store endringer av bosetningen i overgangen mellom eldre og yngre jernalder. Det er en periode hvor det skjedde flere store samfunnsmessige endringer i Nord- og Sentral-Europa - kulturelt, økologisk og økonomisk (for eksempel Myhre 2002:172-173; Gräslund og Price 2012; Iversen 2017b). Dette reflekteres blant annet i bosetningsmønsteret, der en del gårder legges ned (Gjerpe 2017), mens en mindre del opprettholdes (Gräslund 2007:114; Göthberg 2007). Noen stedsnavnsforskere anser at om en kan vise kontinuitet i bosetningen tilbake til eldre jernalder, må de eldste navnene som kan spores, være minst like gamle, for eksempel Säby, Kyrsta, Apalle i Sverige (Vikstrand 2015), eller betraktelig eldre (Vikstrand 2013:14 og der anført litteratur). Andre forskere er skeptiske til kontinuitet over så lange tidsspenn (Pilø 2005; Gjerpe 2014, 2017). En må, som Andrén (1997) understreker, vurdere konteksten for å kunne komme nærmere tingets alder. Hvordan var så tinget i den perioden vi kan spore det eldste stedsnavnstingstedet og det arkeologiske tingstedet til?

Selv om en må være varsom, er det ikke til å komme bort fra at navnet på flere stammer referert til av de klassiske forfatterne antagelig kan identifiseres i senere distrikter, og der flere kan gjenfinnes i dag. Det er da nærliggende å tenke seg at de må ha hatt et felles møtested og sentralsted (Brink 2008a). På kontinentet og De britiske øyer med betydelig eldre skriftkilder enn i Norden viser lover til ting og faste lovområder alt fra rundt 500 e.Kr. (von Amira 1913; Wenkus 1984; Barnwell 2003; Iversen 2013). Forekomsten av ordet ting, belagt i formen Thincso, kanskje alt rundt 200 e.Kr., og germanske gruppers ting omtalt av Cæsar 50 f.Kr. underbygger ytterligere de lange linjene i tinginstitusjonen.

Tacitus (kap. 11) beskriver i 98 e.Kr. to institusjoner hos germanerne - krigerfølget (centena) og tinget (concilium). De germanske stammene skal ha hatt ledere omgitt av edsvorne krigere på opptil hundre mann, slik betydningen av de senere administrative inndelingsnavnene hund, herred og hundare er tolket til også i Norden (for eksempel Andersson 1979, 1999). Krigerfølget skal ha ivaretatt den lokale rettsutøvelsen i hver administrative lokalenhet, pagus (Hedeager 2001:104; Iversen 2013). Det kan tyde på at høvdingen og følget hadde sin opprinnelse på tinget og en offentlig funksjon knyttet til rettsutøvelse og krig (Hedager 2001). Som nevnt er det også argumentert for at den svenske hund-inndelingen indirekte kan vise til grupper på hundre menn (Andersson 2014). Flere likheter kan spores mellom germanernes ting og det i Skandinavia over tusen år senere, blant annet knyttet til tingets fredhellige karakter (det måtte ikke brytes ved vold), fast møtetid og sted, og vedtak som måtte godkjennes av tingforsamlingen ved våpentak, det vil si løfte våpnene, en praksis som også gjenfinnes i administrative inndelingsnavn i Danelagen i vikingtid, såkalte weapentake (Iversen 2013; Sanmark 2017). Prinsippet om delegater var heller ikke ukjent for germanerne. Ifølge Tacitus skulle utsendinger møtes til faste kultmøter (kap. 39), som synes å tilsvare et høyere rettsnivå, men det er likevel noe usikkert. 
Folk i Norden levde ikke isolert fra Romerriket. Det vitner for eksempel våpengraver her i landet om, tolket som gravene til returnerte leiesoldater fra den romerske hær (Myhre 2002:160-169; Ystgaard 2014:275-276). Påvirket av romerne i tiden rundt Kristi fødsel ble det germanske samfunnet i Norden i løpet av et par hundre år et helt annet og mer hierarkisk samfunn. Det reflekteres i både grav- og boplassfunn og omlegginger av driftsformer i jordbruket. Krigsbytteofringer i danske myrer, fra rundt 200 e.Kr. og utover, viser at folk i nord hadde fått en avansert form for militær organisering (Solberg 2000:69; Hedeager 2001:85). Samtidig anlegges handelsplasser som Lundeborg og Helgø, som vitner om administrert handel og vareutveksling etter fastsatte priser. Et eget skriftsystem med runer oppsto også i Norden på det tidspunktet. Alt i alt indikerer det at samfunnet må ha endret seg grunnleggende (Solberg 2000:123). I denne perioden etableres også ringtunene i Vest- og Nord-Norge.

Selv om en ikke kan vite det sikkert, kan romernes ekspansjon ha blitt ansett som en trussel her i nord. I 83-84 e.Kr. sto den romerske flåten utenfor kysten av Elgin i Skottland, bare få dagers seilas fra vestlandskysten (Iversen 2015a:103 med referanser). En kan jo undres om ikke det kan ha medført en organisering på høyere nivå og en styrket regulering av landskapet enn tidligere i Norden, som særlig har latt seg spore arkeologisk på vest- og nordkysten av Norge. Så kan en jo spørre seg hvorfor ikke ringtun oppsto andre steder i Norden. Her kan det være nærliggende å anta at det kan ha vært ulik samfunnsorganisering som gav seg uttrykk i andre anlegg, kanskje ikke like sporbare, som kokegropfelt - som fikk økt bruk i nettopp romertid. Som nevnt er det mulig at også disse feltene kan kobles til administrative inndelinger der tinget har gitt navn til distrikter (Ødegaard i trykk), ikke ulikt situasjonen som kan gjenfinnes senere i vikingtid og middelalder (Andersson 1965; Svensson 2015a).

Som det fremkom av definisjonen av institusjon påpekt innledningsvis, var et av punktene om det innehadde en offentlig karakter. Hadde tinget i romertid en slik offentlig karakter som i vikingtid i form av en organisasjon? Dersom en med offentlig mener organisasjon av en vidtgående samfunnsmessig karakter, er dette oppfylt. Ettersom alle frie og fullmyndige menn møtte på tinget (Sanmark 2017:40-41), ble det en viktig rettslig-politisk arena for et større kollektiv av frie menn, som trolig også hadde militære plikter. Det som er vesentlig er at disse møtene fikk makt til å legitimere politiske og judisielle handlinger nettopp på bakgrunn av mengden mennesker som møtte (Wickham 2009:101). Kollektivet kan altså være en maktfaktor i samfunnet, som også bevitnes i hund-inndelingene i Mälar-landskapet. Disse utviser paralleller til de jevnstore jernalderbygdene som dermed ikke nødvendigvis forutsetter at en overregional makt har innført dem (Zachrisson 2013:173). Tinginstitusjonen var neppe like stabil og forutsigbar i romertiden som i middelalderen, men arkeologisk materiale understreker sosialt fellesskap og avanserte former for sosial og militær organisasjon som indikerer former for institusjonelt fellesskap mellom mennesker. Ringtunene og kokegropfeltene vitner om samhandling og gjentatte, tilbakevendende samlinger knyttet til faste geografiske områder alt fra 100-tallet og kontinuitet over et svært stort tidsrom.

En begynner å få en større forståelse for hvordan et tingsted kan ha sett ut $\mathrm{i}$ jernalderen på sentrale, navngitte steder i landskapet, som tunanlegg og kokegropfelt. Kanskje var stedene knyttet til visse fornlevninger som gravhauger og reiste steiner, og antagelig også relatert til relativt faste geografiske områder. Eksempelet fra kokegropfeltet på Lystad viser likevel at det ikke er entydig, og at det har skjedd mange endringer i både møteplasser og administrative områder gjennom forhistorien. For å nærme oss tingets alder er en kombinasjon av kilder nødvendig, og som vist er stedsnavn og arkeologi, sammen med historie og geografi, viktig kilder. 


\section{Konklusjon}

Arkeologi og stedsnavn kan ikke hver for seg belyse tinginstitusjonens alder, men med komparativ bruk der alt tilgjengelig materiale inkluderes, er det her sannsynliggjort at tinget som institusjon kan strekke seg tilbake til eldre romertid. Arkeologiske spor i sin videre kontekst kan trekke tinginstitusjonen lenger tilbake i tid enn stedsnavnsgranskningen foreløpig har kunnet gjøre. For å belyse tinget er både stedsnavn og arkeologi gjensidig avhengige og utfyller hverandre. Og som vist, når de to kildekategoriene er i motstrid med hverandre, kan det skyldes endringer eller eventuelt metodiske feil som må løses. Nye studier vil trolig gi en større forståelse av dybden av tingorganisasjonen enn tidligere. Det er klare fellestrekk i organisasjonen langt bakover i forhistorien. Skriftlige kilder fra 100 e.Kr og det indirekte belegg for ting belagt som Thincso på 200-tallet og lover og rettsnivåer fra 500tallet viser at tinget som institusjon eksisterte i eldre romertid blant germanske stammer på kontinentet. Selv om en ikke må tilbake til noe germansk felles- og likhetsideal - som også med rette er blitt kritisert - så er det mange beskrivelser, ikke minst i Tacitus' beskrivelse av germanerne, som kan gjenfinnes her i Norden 1000 år senere, og det synes ikke tilfeldig. Som mitt eksempel fra Tjølling viste, kan vi kanskje ane konturene av det noe lenger tilbake, til førromersk jernalder. Kombinasjon av stedsnavn og arkeologi er slik viktige kilder til å datere tingsteder og avdekke eventuelle endringer i organisasjon, inndelinger og tingsteders lokalisering.

\section{Takk}

Takk til Torun Zachrisson, Magne Njåstad og Randi Barndon som gav meg en spennende tittel på prøveforelesningen, noe som danner bakgrunn for denne teksten. En takk går også til fagfellen som gav gode innspill på artikkelen.

\section{Summary}

The age of the thing institution in Scandinavia as indicated by archaeological evidence and place name studies - correspondence or discrepancy?

The age of the legal assemblies in Scandinavian, the Old Norse thing, is obscure. The sources, which best can shed light on the prehistoric situation, are archaeology and place names. To discuss this, two analytical categories are defined, «the archaeological thing site» and «the place name thing site» and whether the two categories affirm, supplement or contradict each other. Different thing-sites are discussed, especially those that are most recently argued to be thing sites from the early Iron Age. It is argued that archaeology and place names cannot individually shed light on the age of the thing institution, but with comparative use, where all available material is included, it has been shown to be probable that the thing, as an institution, extends back to the Early Roman Iron Age. Archaeological traces in their wider context can extend the thing institution further back in time than place-name research has been able to do for the time being. Nevertheless, to throw light on the age of the thing, both place names and archaeology are dependent of and complementary to each other. 


\section{Litteratur}

Andersen, Niels H.

2004 Sarup. Causewayed enclosures placed in a Neolithic ritual landscape on Funen,

Denmark. Journal of Nordic Archaeological Science 14:11-17.

Andersson, Thorsten

1965 Svenska häradsnamn. Nomina Germanica, vol. 14. Lund.

1979 Die schwedischen Bezirksbezeichnungen hund und hundare. Ein Beitrag zur Diskussion einer germanischen Wortfamilie. Frühmittelalterliche Studien 13:24-88.

1982 Danska häradsnamn: Olika typer i formellt hänseende. Namn och bygd 76:46-76.

1999 Hundare och det germanska hundratalet. Namn och bygd 87:5-12.

2000 Hund. I Reallexikon der Germanischen Altertumskunde, vol. 15, redigert av Johannes Hoops, s. 233-238. de Gruyter, Berlin.

2004 Svethiudh, det svenska rikets kärna. Namn och bygd 92:5-18.

2014 Nordiska distriktsbeteckningar i gammal tid. Namn och bygd 102:5-40.

Andrén, Anders

1997 Mellan ting och text: en introduktion til de historiska arkeologiarna. Brutus Östlings bokförlag Symposio, Stockholm.

Baker, John og Stuart Brookes

2013 Monumentalising the Political Landscape: A Special Class of Anglo-Saxon Assembly Sites. The Antiquaries Journal 93:147-162.

2015 Identifying outdoor assembly sites in early medieval England. Journal of Field Archaeology, vol. $40(1): 3-21$.

Barnwell, Paul S.

2003 Political Assemblies: Introduction. I Political Assemblies in the Early Middle Ages, redigert av Paul S. Barnwell og Marco Moster, s. 1-10. Studies in the Early Middle Ages, vol. 7. Brepols, Turnhout.

Bjorvand, Harald og Fredrik Otto Lindeman

2000 Våre arveord. Etymologisk ordbok. Instituttet for sammenlignende kulturforskning, Serie B Skrifter 105. Novus forlag, Oslo.

Brendalsmo, Jan

2003 Tjølling kirke. Om en basilika, en kaupang og en storgård. I Tjølling kirke. Veien, sannheten og livet $i$ bygda gjennom 850 år, redigert av Ingvar Skarvang, s. 22-38. Tjølling felleskirkelige råd, Tjølling.

Brink, Stefan

1990 Cult sites in northern Sweden. I Old Norse and Finnish religions and cultic place-names: based on papers read at the Symposium on Encounters between Religions in Old Nordic Times and on Cultic Place-Names held at Åbo, Finland, on the 19th-21st of August 1987, redigert av Tore Ahlbäck, s. 458-489. Scripta 13, Åbo.

1996a Political and Social Structures in Early Scandinavia: A Settlement-historical Pre-study of the Central Place. Tor 28:235-281.

$1996 \mathrm{~b}$ Forsaringet - Nordens äldsta lagbud. I Beretning fra femtende tvcerfaglige vikingesymposium, redigert av Else Roesdahl, s. 27-55. Forlaget Hikuin og Afdelingen for Middelalder-arkæologi, Højbjerg.

1998 Land, bygd, distrikt och centralort i Sydsverige. Några bebyggelseshistoriska nedslag. I Centrala Platser, Centrala Frågor. Samhällsstrukturen under Järnåldern. En Vänbok till Berta Stjernquist, redigert av Lars Larsson og Birgitta Hårdh, s. 297-336. Uppåkrastudier 1. Acta Archaeologica Lundensia Series in $8^{\circ}$, No 28. Almqvist \& Wiksell Interenational, Stockholm.

2003 Legal Assemblies and Judical Structure in Early Scandinavia. I Political Assemblies in the Earlier Middle Age, redigert av Paul S. Barnwell og Marco Mostert, s. 61-72. Studies in the Early Middle Ages Volume 7. Brepols, Turnhout. 
2004 Legal assembly sites in early Scandinavia. I Assembly Places and Practices in Medieval Europe, redigert av Aliki Pantos og Sarah Semple, s. 205-216. Four Courts Press, Cornwall.

2007 Skiringssal, Kaupang, Tjølling - the Toponymic Evidence. I Kaupang in Skiringssal, redigert av Dagfinn Skre, s. 53-64. Kaupang Excavation Project 22, vol. 1. Norske Oldfunn XXII. Aarhus University Press, Århus.

2008a Naming the land. I The Viking World, redigert av Stefan Brink og Neil Price, s. 57-66. Routledge, London.

2008b People and Land in Early Scandinavia. I Franks, Northmen, and Slavs: identities and state formation in early medieval Europe, redigert av Ildar H. Garipzanov, Patrick J. Geary og

Bull, Edvard Przemysłav Urbańczyk, s. 87-112. Cursor mundi, vol. 5. Brepols, Turnhout.

1920 Leding. Militcer- og Finansforfatning $i$ Norge $i$ ældre tid. Steenske Forlag, Kristiania og København.

1930 Fylke. Scandia 1930:78-105.

1931 Fra omkring 1000 til 1280. Det Norske folks liv og historie gjennem tidene, bind 2. Aschehoug, Oslo.

Byock, Jesse L.

2001 Viking Age Iceland. Penguin Books, London.

Bäck, Mathias og Ann-Mari Hållans Stenholm

2012 Lilla Ullevi: den heliga platsens geografi. Riksantikvarieämbetet, Hägerstein.

Christensen, Aksel E.

1969 Vikingetidens Danmark paa oldhistorisk baggrund. Gyldendal, København.

Dahl, Ottar

1990 Norsk historieforskning i det 19. og 20. århundre. Universitetsforlaget, Oslo.

Dalberg, Vibeke og John Kousgård Sørensen

1979 Stednavneforskning 2. Udnyttelsesmuligheder. Akademisk forlag, København.

Den Jyske Lov. Text med oversættelse, kommentar ved Peter Skautrup. Bind II.

1941 [1241] Jysk selskab for historie, sprog og litteratur. Reitzel, København.

DN: Diplomatarium Norvegicum. Oldbreve til kundskab om Norges indre og ydre forhold, sprog, slagter, sceder, lovgivning og rettergang i middelalderen. Utgitt av Christian Christoph Andreas Lange, Carl Richard Unger mfl. 1874-2001. 23 bind. Christiania/Oslo.

Douglas, Mary

1986 How Institutions Think. Syracuse University Press, Syracuse.

Dodgshon, Robert A.

1998 Society in time and space: a geographical perspective on change. Cambridge studies in historical geography 27. Cambridge University Press, Cambridge.

Durkheim, Émile

2001 [1894] Selvmordet: en sosiologisk undersøkelse. Oversatt av Halvor Roll, 3. utgave. Gyldendal, Oslo.

F: Frostatingslova. Omsett av Jan Ragnar Hagland og Jørn Sandnes 1994. Norrøne bokverk.

Det Norske Samlaget, Oslo.

Edlund, Lars-Erik, Östen Dahl og Leif Wastenson

2010 Sveriges nationalatlas: Språken i Sverige. Norstedts förlagsgrupp, Stockholm.

Ersland, Geir Atle

2000 Kongshird og leidangsbonde. I Norsk forsvarshistorie, Bind 1, Krigsmakt og kongemakt

Fenger, Ole 900-1814, del 1, redigert av Geir Atle Ersland og Terje H. Holm, s. 11-154. Eide forlag, Bergen.

1991 Germansk retsorden med særligt henblik på det 7. århundrede. I Fra Stamme til Stat i Danmark, bind 2. Høvdingesamfund og Kongemagt, redigert av Peder Mortensen og Birgit M. Rasmussen, s. 155-164. Aarhus universitetsforlag, Aarhus. 
Foucault, Michel

1999 [1974] Overvåkning og straff. Det moderne fengsels historie. Oversatt av Dag Østerberg. Gyldendal, Oslo.

Fritzner, Johan

1896 Ordbog over Det gamle norske Sprog IIII. Feilberg \& Landmark, Kristiania.

G: Den eldre Gulatingslova. Utgitt ved Bjørn Eithun, Magnus Rindal og Tor Ulset. 1994. Norrøne tekster nr. 6. Riksarkivet, Oslo.

Gjerpe, Lars Erik

2001 Kult, politikk, fyll, vold og kokegropfeltet på Hov. Primitive tider 4:5-17.

2014 Kontinuitet i jernalderens bosetning. Et udatert postulat arvet fra 1814-generasjonen? Viking 77:55-78.

2017 Effektive hus. Bosetning, jord og rettigheter på Østlandet i jernalder. Upublisert PhD-avhandling. Det humanistiske fakultet, Universitetet i Oslo.

Glørstad, Håkon og Steinar Solheim

2015 The Hamremoen enclosure in southeastern Norway. An exotic glimpse into the process of Neolithization. I Neolithic Diversities. Perspectives from a conference in Lund, Sweden, redigert av Kristian Brink, Susan Hydén, Kristina Jennbert, Lars Larsson og Deborah Olausson, s. 139-152. Acta Arcaheologica Lundensia, Series in $8^{0}$, No. 65. Elanders Fälth \& Hässler, Värnamo.

Gräslund, Bo

2007 Fimbulvintern, Ragnarök och klimatkrisen år 536-537 e.Kr. Saga och Sed:93-123.

2010 Om relationen mellan arkeologi och ortnamnsforskning. Med en diskussion om ägonamn, plurala bebyggelsenamn och begrepet gård. Namn och bygd 98:45-63.

Gräslund, Bo og Neil Price

2012 Twilight of the gods? The «dust veil event» of AD 536 in critical perspective. Antiquity 86:428443.

Gustafson, Lil, Tom Heibreen og Jes Martens (red.)

2005 De gåtefulle kokegroper. Varia, vol. 58. Kulturhistorisk Museum, Fornminneseksjonen, Universitetet i Oslo, Oslo.

Göthberg, Hans

2007 Mer än bara hus och gårdar. I Hus och bebyggelse i Uppland. Delar av förhistoriska sammanhang, redigert av Hans Göthberg, s. 403-445. Arkeologi E4 Uppland. Studier, vol. 3. Upplandsmuseet Riksantikvarieämbetet Societas Archaeologica Upsaliensis, Uppsala.

Habbe, Peter

2005 Att se och tänka med ritual. Kontrakterande ritualer i de isländska släktsagorna. Vägar till Midgård, vol. 7. Nordic Academic Press, Lund.

Hald, Kristian

1980 [1961] Herredsnavne. I Kulturhistorisk leksikon for nordisk middelalder, bind VI, 2. opplag, redigert av George Rona, s. 497-498. Rosenkilde og Bagger, København.

1965 Vare Stedsnavne. Gads Forlag, København.

Hedblom, Folke

1958 Gästriklands äldre bebyggelsenamn. En förberedande undersökning. Særtrykk av Från Gästrikland, 1957/1958. Gästriklands kulturhistoriska förening. Gävle.

Hedeager, Lotte

2001 Det frie Germania. I Tusen års europahistorie. Romere, germanere og nordboere, redigert av Lotte Hedeager og Henrik Tvarnø, s. 98-114. Pax, Oslo.

Hellberg, Lars

1967 Ortnamn och ældre bebyggelse. Kumlabygden: Forntid - nutid - framtid, vol. 3. Kumla. 
1975 Ortnamnen och den forntida sveastaten. I Inledningar till NORNAs fjärde symposium Ortnamn och Samhälle på Hanaholmen den 25.-27.4 1975. 1. Namngivning, redigert av Vibeke Dalberg, s. 92-110. Uppsala.

Helliksen, Wenche

2009 Kokegroper. Fasanhagan-Solsletta, Lystad, 128/5, 187. Sandefjord kommune, Vestfold Fylke, Rapport fra arkeologisk utgravning. Upublisert utgravningsrapport, Kulturhistorisk Museum, Universitetet i Oslo.

Henriksen, Mogens Bo

1999 Bål i lange baner - om brugen af kogegruber i yngre bronzealder og ældre jernalder. Fynske Minder 1999:93-128.

2005 Danske kogegrober og kogegrubefelt fra yngre bronzealder og ældre jernalder. I De gåtefulle kokegroper, redigert av Lil Gustafson, Tom Heibreen og Jes Martens, s. 77-103. Varia, vol. 58. Kulturhistorisk museum, Fornminneseksjonen, Universitetet i Oslo, Oslo.

Hyltén-Cavallius, Gunnar Olof

1868 Wärend och Wirdarne. Ett försök i Svensk Ethnologi, 2. P.A. Nordstedt och söner, Stockholm. Indrebø, Gustav

1931 Fylke og fylkesnamn. Bergens museums årbok 1931. Historisk-antikvarisk rekke, Bergen.

1935 Fjordung. Granskingar i eldre norsk organisasjons-soge. Bergens Museums Årbok 1935. Historisk-antikvarisk rekke nr. 1, Bergen.

Iversen, Frode

2013 Concilium and Pagus - Revisiting the Early Germanic Thing System of Northern Europe. Journal of the North Atlantic Special Volume 5:5-17.

2015a Community and Society: The Thing at the Edge of Europe. Journal of the North Atlantic Special Volume 8:5-21.

2015b Houses of commons. Houses of Lords? The Thing on the Threshold of Statehood in Rogaland, Western Norway in the Merovingian and Viking Ages. I Nordic Middle Ages - Artefacts, Landscapes and Society. Essays in Hounour of Ingvild Øye on her $70^{\text {th }}$ Birthday, redigert av Irene Baug, Janicke Larsen og Sigrid Samset Mygland, s. 175-192. UBAS 8. University of Bergen Archaeological Series. University of Bergen, Bergen.

2017a Courtyard sites and their cultic context. I Religion, cult and rituals in the medieval rural environments, redigert av Christine Bis-Worch og Claudia Theune, s. 25-37. Ruralia XI. Sidestone Press, Leiden.

2017b Estate Division: Social Cohesion in the Aftermath of AD 536-7. I The Agrarian Life of the North 2000 BC-AD 1000. Studies in Rural Settlement and Farming in Norway, redigert av Frode Iversen og Håkan Petersson, s. 41-75. Portal, Kristiansand.

Jensen, Ola W.

2002 Forntid i historien: en arkeologihistorisk studie av synen på forntid lämningor, från medeltiden till och med förupplysningeen. Gothenburg Archaeological Theses, vol. 19, Göteborg.

Johansen, Olav Sverre og Tom Søbstad

1978 De nordnorske tunanleggene fra jernalderen. Viking 41:9-56.

Jørgensen, Bent

1980 Stednavne og administrationshistorie. Navnestudier, vol. 20. Akademisk forlag, København.

Keyser, Rudolf

1867 Norges Stats- og Retsforfatning i Middelalderen. Efterladte Skrifter 2:1. Malling, Christiania.

Kristoffersen, Elna Siv, Marianne Nitter og Einar Solheim Pedersen (red.)

2014 Et Akropolis på Jceren? Tinghaugplatået gjennom jernalderen. AmS-Varia, vol. 55. Arkeologisk museum, Universitetet i Stavanger, Stavanger.

Koht, Halvdan

1921 Innhogg og utsyn i norsk historie. Aschehoug, Kristiania. 
Lewis, Charlton T. og Charles Short

1879 A Latin Dictionary. Elektronisk dokument, http://www.perseus.tufts.edu/hopper/ text?doc $=$ Perseus:text:1999.04.0059:entry $=$ centuria\&highlight $=$ centenarius, besøkt 20 . februar 2018.

Lillehammer, Grethe

2014 Jærens Akropolis. Landskap og fornminner på Anda-/Tuhøyden. I Et Akropolis på Jceren. Tinghaugplatået gjennom jernalderen, redigert av Elna Siv Kristoffersen, Marianne Nitter og Einar Solheim Pedersen, s. 13-36. AmS-Varia, vol. 55. Arkeologisk museum i Stavanger, Stavanger.

Martens, Jes

2005 Kogegrober i syd og nord - samme sag? I De gåtefulle kokegroper, redigert av Lil Gustafson, Tom Heibreen og Jes Martens, s. 37-56. Varia, vol. 58. Kulturhistorisk museum, Fornminneseksjonen, Universitetet i Oslo, Oslo.

Meaney, Audrey

1997 Hundred Meeting-Places in the Cambridge Region. I Names, Places and People. An Onomastic Miscellany in Memory of John McNeal Dodgson, redigert av Alexander R. Rumble og Anthony David Mills, s. 195-239. Paul Watkins, Stamford.

Mehler, Natascha

2015 Pingvellir: A Place of Assembly and a Market? Journal of the North Atlantic Special Volume 8:69-81.

Moseng, Ole Georg

1994 Sigden og Sagbladet. Eikers historie, bind II. Øvre og Nedre Eiker kommuner, Hokksund.

Munch, Peter Andreas

1849 Historisk-geographisk Beskrivelse over Kongeriget Norge (Norgesveldi) i Middelalderen. Gram, Moss.

Myhre, Bjørn

2002 Landbruk, landskap og samfunn 400 f.Kr.-800 e.Kr. I Norges landbrukshistorie 1. 400 f.Kr. - 1350 e.Kr. Jorda blir levevei, redigert av Bjørn Myhre og Ingvild Øye, s. 12-214. Det Norske Samlaget, Oslo.

Narmo, Lars Erik

1996 «Kokekameratene på Leikvin». Kult og kokegroper. Viking 59:79-100.

NG: Norske Gaardnavne oplysninger samlede til brug ved matrikelens revision I-XIX. Utgitt ved Oluf Rygh 1833-1899. Fabritius, Kristiania.

Nordén, Arthur

1938 Tingfjäl och bäsing: en studie över rätter tingstads inrättning. Fornvännen 33:283-300.

Norsk riksmålsordbok (NRO)

2018 Institusjon. Norsk riksmålsordbok. Elektronisk dokument, https://www.ordnett.no/search?langua $\mathrm{ge}=$ no\&phrase $=$ institusjon\&searchmodes $=\&$ selectedPubs $=6$, besøkt 20. februar 2018 .

NRJ: Norske Regnskaber og Jordebøger fra det 16.de Aarhundrede.

Utgitt ved H.J. Huitfeldt-Kaas 1887-1906. Det Norske historiske Kildeskriftfond, Christiania.

Nyström, Staffan

2013 Tolkningsmetodik. I Namn och namnforskning: Ett levande läromedel om ortnamn, personnamn och andra namn. Version 1 (2013-02-19), redigert av Staffan Nyström, Eva Brylla, Märit Frändén, Mats Wahlberg og Per Vikstrand, s. 26-28. Uppsala universitet, Uppsala.

Olsen, Magnus

1915 Hedenske kultminder i norske stedsnavne 1. Videnskabsselskapets Skrifter II, Historisk-filosofisk klasse 1914(4). Jacob Dybwad, Kristiania.

1926 Ættegård og helligdom. Norske stedsnavn sosialt og religionshistorisk belyst. Instituttet for sammenlignende kulturforskning 9a, Serie A, Forelesninger. Aschehoug, Oslo. 
Olsen, Morten

2003 Den sosio-politiske organiseringen av Jæren i eldre jernalder. Et tolkningsforsøk med utgangspunkt i skriftlige kilder og tunanleggene. Upublisert masteroppgave, University of Tromsø, Tromsø.

Pantos, Aliki

2004 In medle oððe an pinge: the Old English vocabulary of assembly. I Assembly places and practices in medieval Europe, redigert av Aliki Pantos og Sarah Semple, s. 181-201. Four Courts Press, Dublin.

Pamp, Bengt

1974 Ortnamnen i Sverige. Lundastudier i nordisk språkvetenskap. Serie B, vol. 2. Lund.

Pilø, Lars

2005 Bosted-urgård - enkeltgård. En analyse av premissene i den norske bosetningshistoriske forskningstradisjonen. Oslo Arkeologisk Serie, vol. 3. Universitetet i Oslo, Oslo.

Ruthström, Bo

1990 Forsa-ringen - vikingatida vi-rätt? Arkiv för nordisk filologi 105:41-56.

Sandnes, Jørn og Ola Stemshaug

1976 Norsk stadnamnleksikon. Det Norske Samlaget, Oslo.

Sandvik, Gudmund

1989 Europeisk rettshistorie i mellomalderen. Førelesningar. I Jussens venner 24, redigert av Marie-Louise Holmstedt og Sven Marius Urke, s. 201-309. Hefte 6/7-1989. Universitetsforlaget, Oslo.

Sanmark, Alexandra

2009 Administrative Organisation and State Formation: A Case Study of Assembly Sites in Södermanland, Sweden. Medieval Archaeology 53:205-241.

2017 Viking Law and Order. Places and Rituals of Assembly in the Medieval North. Edinburgh University Press, Edinburgh.

Sanmark, Alexandra og Sarah Semple

2010 The Topography of Outdoor Assembly in Europe with Reference to Recent Field Result from Sweden. I Perspectives in Landscape Archaeology. Papers presented at Oxford 2003-5, redigert av Helen Lewis og Sarah Semple, s. 107-119. BAR International Series, vol. 2103. Archaeopress, Oxford.

2013 Assembly in North West Europe: collective concerns for early societies? Journal of European Archaeology 16 (3):518-542.

Schledermann, Helmuth

1982 Tingsted. I Kulturhistorisk leksikon for nordisk middelalder, bind XVIII, 2. opplag, redigert av George Rona, s. 373-376. Rosenkilde og Bagger, København.

Seip, Jens Arup

1934 Lagmann og lagting i senmiddelalderen og det 16de århundre. Skrifter utgitt av Det Norske Videskaps-Akademi i Oslo II. Historisk-Filosofisk klasse 1934(3). Dybwad, Oslo.

Semple, Sarah

2004 Locations of assembly in early Anglo-Saxon England. I Assembly Places and Practices in Medieval Europe, redigert av Aliki Pantos og Sarah Semple, s. 135-154. Four Courts Press, Cornwall.

Semple, Sarah, Alexandra Sanmark, Frode Iversen og Natascha Mehler (red.)

2019 The Thing in the North. Society for Medieval Archaeology. Maney \& Sons, London, i trykk.

Skirbekk, Sigurd

2015 Institusjon. I Store norske leksikon. Elektronisk dokument, https://snl.no/institusjon, besøkt 20. februar 2018 .

Skre, Dagfinn (red.)

2007 Kaupang in Skiringssal. Kaupang Excavation Project, vol. 1. Norske Oldfunn XXII. University of Oslo. Aarhus University Press, Århus. 
Solberg, Bergljot

2000 Jernalderen i Norge: ca. 500 f.Kr-1030 e.Kr. Cappelen akademisk forlag, Oslo.

Stefánsson, Magnus

1984 Ding §16, Island. I Reallexikon der Germanischen Altertumskunde, vol. 5, redigert av Johannes Hoops, s. 461-464. Walter de Gruyter, Berlin.

Steinnes, Asgaut

1929 Kor gamal er den norske leidangsskipnaden? Syn og Segn 35:49-65.

Storli, Inger

2006 Hålogaland før rikssamlingen. Politiske prosesser i perioden 200-900 e.Kr. Instituttet for sammenlignende kulturforskning, Serie B, Skrifter, vol. 123. Novus forlag, Oslo.

Storm, Gustav

1901 Skiringssal og Sandefjord. Historisk Tidsskrift 4.R(1):214-237.

Strauch, Dieter

2011 Mittelalterliches nordisches Recht bis 1500. Eine Quellenkunde. Reallexikon der Germanischen Altertumskunde. Ergänzungsband, vol. 73. Walter de Gruyter, Berlin.

Sundqvist, Olof

2007 Kultledare i fornskandinavisk religion. OPIA, vol. 41. Uppsala Universitet, Uppsala.

Svensson, Ola

2015a Nämnda ting men glömda. Ortnamn, landskap och rättsutövning. Upublisert dokorgradsavhandling, Linnéuniversitetet, Växjö.

2015b Place Names, Landscape and Assembly Sites in Skåne, Sweden. Journal of the North Atlantic Special Volume 8:82-92.

Tacitus, Cornelius

1938 [98] Germania. Utgitt av John Graham Comrie Anderson. Clarendon, Oxford.

Tunberg, Sven

1911 Studier rörande Skandinaviens äldsta politiska indelning. K.W. Appelbergs boktryckeri, Uppsala. Vésteinsson, Orri

2013 What is in a Booth? Material Symbolism at Icelandic Assembly Sites. Journal of the North Atlantic Special Volume 5:111-124.

Vikstrand, Per

2001 Gudarnas platser: förkristna sakrala ortnamn i Mälarlandskapen. Kungl. Gustav Adolfs Akademien för svensk folkkultur, Uppsala.

2013 Järnålderns bebyggelsesnamn. Om bebyggelsenamnens uppkomst och ålder i Mälarlandskapen. Institutet för språk och folkminnen. Namnarkivet i Uppsala. Serie B:13. Uppsala.

2015 Rönö hundare och Runtuna. Saga och Sed 2015:41-65.

von Amira, Karl

1913 Grundriss des Germanischen Rechts. Grundriss der Germanischen Philologie, vol. 5. K.J. Trubner, Straßburg.

Weibull, Lauritz

1911 Kritiska undersökningar i Nordens historia omkring år 1000. Gleerup, Lund.

Wenskus, Reinhard

1984 Ding. I Reallexikon der Germanischen Altertumskunde, vol. 5, redigert av Johannes Hoops, s. 443-455. Walter de Gruyter. Berlin.

Wickham, Chris

2009 The Inheritance of Rome. A History of Europe from 400 to 1000. Allen Lane, London.

Wilson, Lars

1994 Runstenar och kyrkor. En studie med utgångspunkt från runstenar som påträffats $i$ kyrkomiljö $i$ Uppland och Södermanland. Occasional papers in archaeology, vol. 8. Societas Archaeologica Upsaliensis, Uppsala. 
Zachrisson, Torun

2013 Gamla Uppsala - på nytt. I Gamla Uppsala i ny belysning, redigert av Olof Sundqvist og Per Vikstrand, s. 161-205. Swedish Science Press, Uppsala.

Ystgaard, Ingrid

2014 Krigens praksis: organisert voldsbruk og materiell kultur i Midt-Norge ca. 100-900 e.Kr.

Upublisert doktorgradsavhandling, Norges teknisk-naturvitenskapelige universitet, Trondheim.

Ødegaard, Marie

2013 State Formation, Administrative Areas, and Thing Sites in the Borgarthing Law Province, Southeast Norway. Journal of the North Atlantic Special Volume 5:42-63.

2015 Tingsted og territorium. Organisering av rettslandskapet i Viken i jernalder og middelalder. Upublisert doktorgradsavhandling, Universitetet i Bergen, Bergen.

2019 Cooking-pit Sites as Possible Assembly Places. Lunde in Vestfold, south-east Norway - Regional Assembly Site in the Early Iron Age? I Power and place in Later Roman and early medieval

Europe: interdisciplinary perspectives on governance and civil organization, redigert av Andrew Reynolds, Jane Carroll and Barbra York. Proceedings of the British Academy, Oxford University Press, Oxford, i trykk.

I trykk Assembling in times of transitions - the case of cooking-pit sites. Ruralia XII, Sidestone Press, Leiden, 2019, i trykk. 